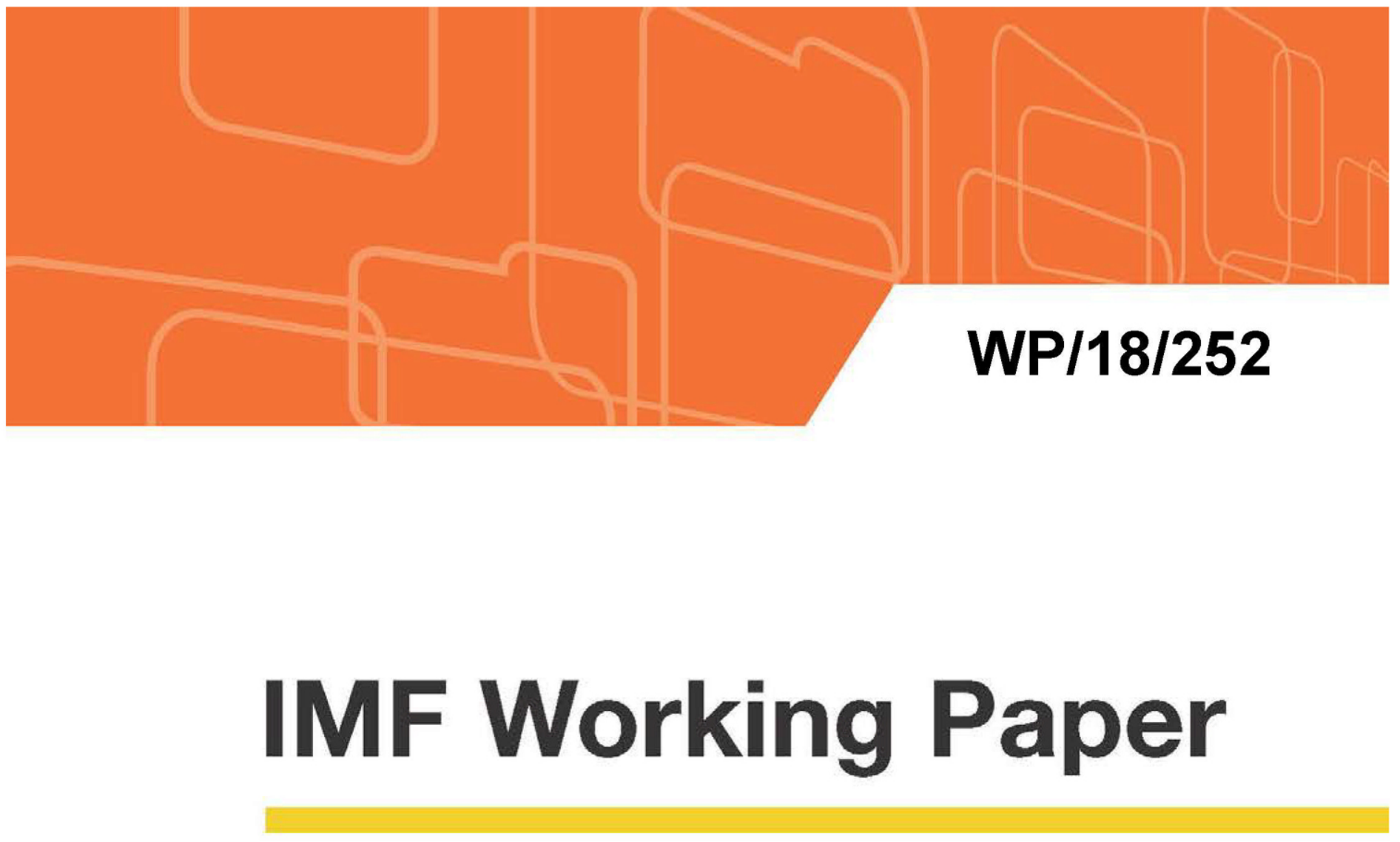

\title{
Regional Labor Mobility in Finland
}

by Tigran Poghosyan

IMF Working Papers describe research in progress by the author(s) and are published to elicit comments and to encourage debate. The views expressed in IMF Working Papers are those of the author(s) and do not necessarily represent the views of the IMF, its Executive Board, or IMF management.

I N T E R N A T I O N A L M O N E T A R Y F U N D 


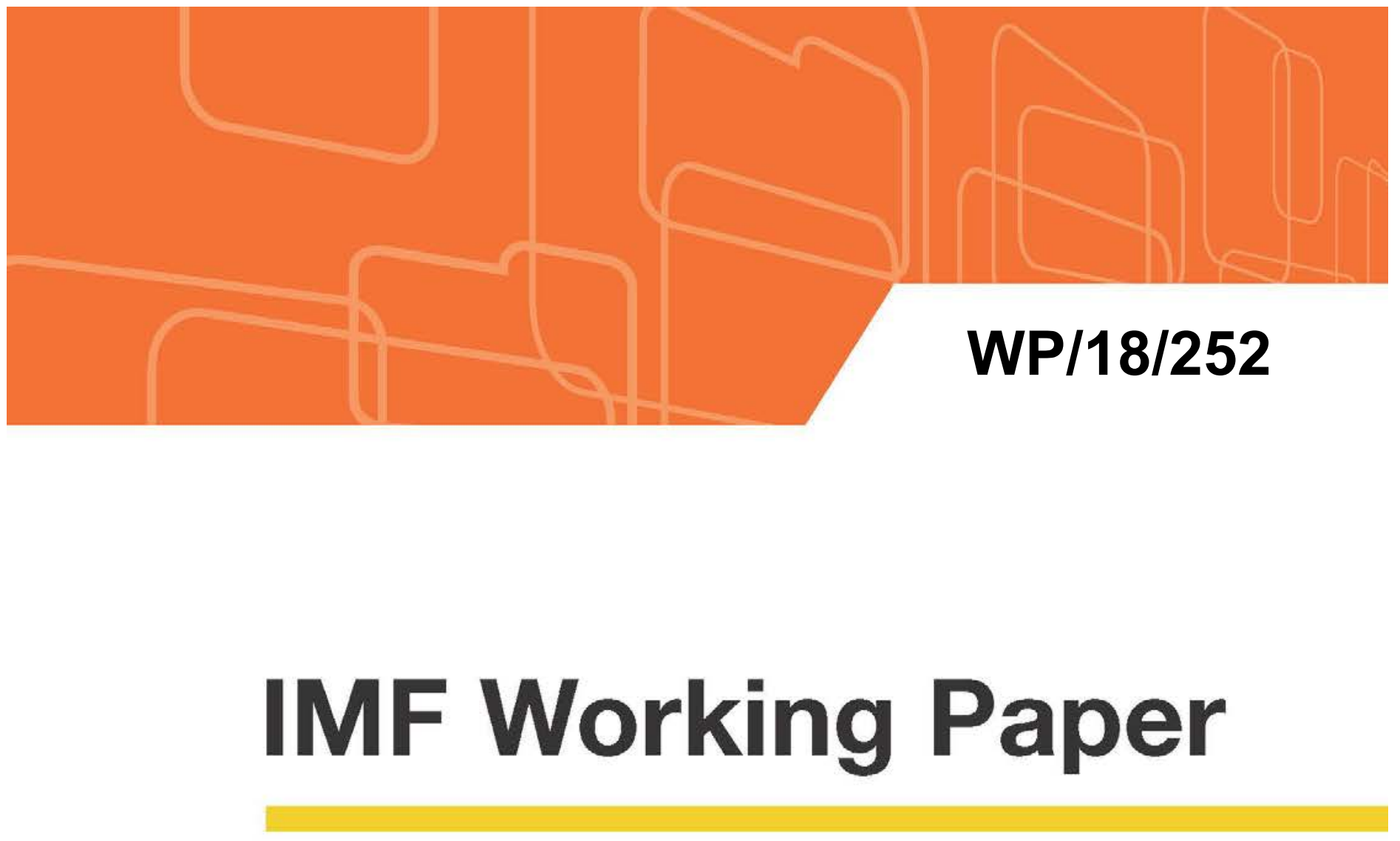

\section{Regional Labor Mobility in Finland}

by Tigran Poghosyan

IMF Working Papers describe research in progress by the author(s) and are published to elicit comments and to encourage debate. The views expressed in IMF Working Papers are those of the author(s) and do not necessarily represent the views of the IMF, its Executive Board, or IMF management.

$$
\text { I N T E R N A T I O N A L M O N E T A R Y F U N D }
$$




\title{
IMF Working Paper
}

\author{
European Department
}

\section{Regional Labor Mobility in Finland}

Prepared by Tigran Poghosyan ${ }^{1}$

Authorized for distribution by Alasdair Scott

November 2018

\section{IMF Working Papers describe research in progress by the author(s) and are published to elicit comments and to encourage debate. The views expressed in IMF Working Papers are} those of the author(s) and do not necessarily represent the views of the IMF, its Executive Board, or IMF management.

\begin{abstract}
This paper analyzes regional labor mobility in Finland using two complementary empirical approaches: a VAR proposed by Blanchard and Katz (1992) and a gravity model. The results point to a relatively limited regional labor mobility in Finland compared to the U.S. and to EU peers. The limited regional labor mobility is associated with persistent unemployment differentials across regions. Some impediments to regional labor mobility are exogenous, such as large geographical distances across regions and relatively sparse population density, and explain about 23 percent of the variation in labor mobility. Others can be influenced by policy, such as further increase in wage flexibiltiy and reduction of housing costs. These impediments explain about 60 percent of the variation in labor mobility. Greater regional labor mobility could help reduce regional unemployment differentials, improve job matching efficiency, and remove pressures from regional fiscal redistribution.

JEL Classification Numbers: J30, J61
\end{abstract}

Keywords: regional labor mobility, gravity model, Finland

Author's E-Mail Address: TPoghosyan@imf.org

\footnotetext{
${ }^{1}$ In addition to the IMF's Finland team, I would like to thank Romain Duval, Christian Henn, Netta Hiitola, Tuomas Kosonen, Annaliina Kotilainen, Davide Malacrino, Jaakko Pehkonen, Matti Saari, and seminar participants at the IMF's European Department and Bank of Finland for helpful comments and suggestions. Ryan Greenaway-McGrevy kindly shared the data for the U.S. Lubai Yang provided excellent research assistance.
} 
Contents

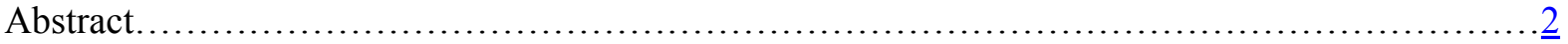

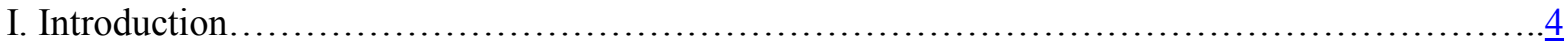

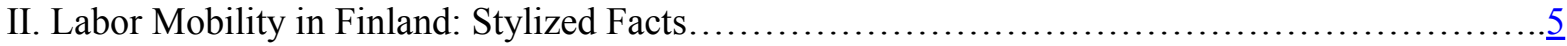

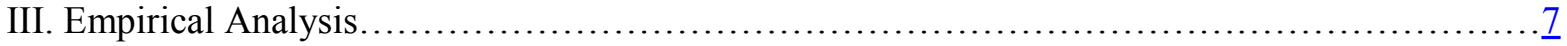

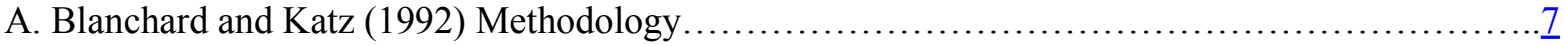

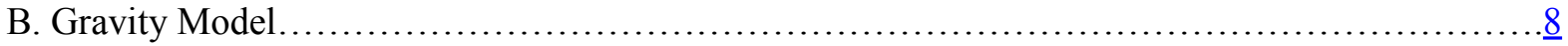

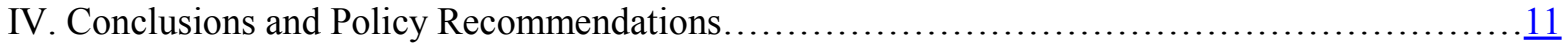

\section{FIGURES}

1. Wage Bargaining Centralization: Finland versus EU Peers...............................

2. Demographic Geography of Finnish Regions..............................................

3. Unemployment Rate: Variation Across Regions and Over Time............................15

4. Labor Force Participation Rate: Variation Across Regions and Over Time..................... $\frac{16}{17}$

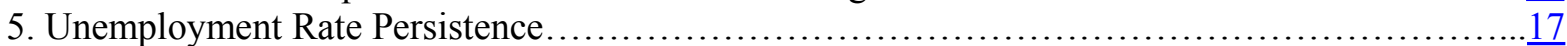

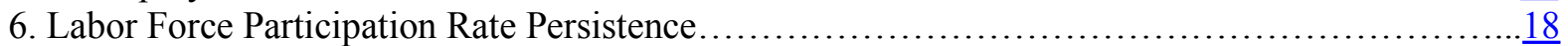

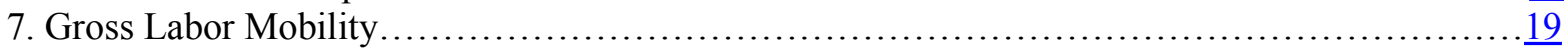

8. In-migration rate: Variation Across Regions and Over Time..............................

9. Out-Migration Rate: Variation Across Regions and Over Time................................

10. Network of Out-Migration Flows Across Pairs of Regions................................22

11. Network of In-migration Flows Across Pairs of Regions...................................

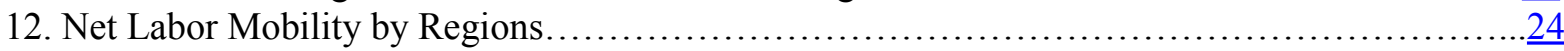

13. House Prices: Variation Across Regions and Over Time.................................. 25

14. Real Wages: Variation Across Regions and Over Time......................................

15. Finland: Blanchard and Katz (1992) Model Replication................................

16. USA: Blanchard and Katz (1992) Model Replication................................... 28

17. Blanchard and Katz (1992) Model Replication: Labor Mobility Response in Finland Versus EU

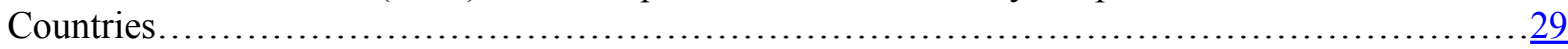

TABLES

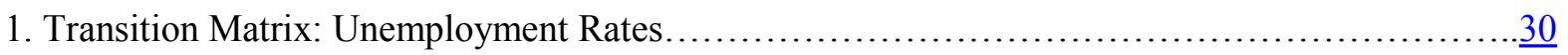

2. Determinants of Regional Labor Mobility: The Gravity Model.............................

\section{ANNEXES}

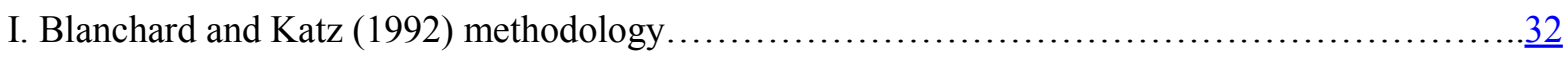

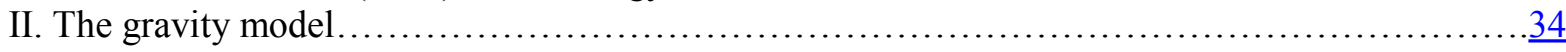

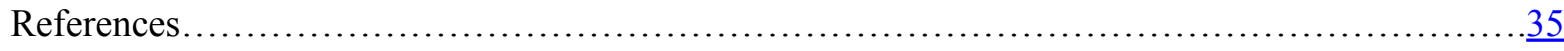




\section{INTRODUCTION}

\section{Previous IMF analysis of Finnish labor markets mainly focused on the national-level indicators, while recognizing the importance of the regional dimension (IMF 2015; IMF} 2017). Regional analysis is warranted as regional labor market outcomes underpin developments at the national level. Labor shortages in some regions frequently coexist with persistently high unemployment in other regions. Part of regional disparities could be explained by fundamental differences across regions, such as characteristics of the regional population, industrial structure, and geography. However, regional disparities could also be a consequence of policy distortions that hamper the adjustment to regional shocks, imposing welfare costs on regions and inflating structural unemployment at the national level. Therefore, addressing the regional dimension of labor market issues should be part of a strategy to reduce structural unemployment.

This paper complements past IMF research by focusing on regional labor mobility. Regional labor markets could be characterized by a "challenging trinity". Countries find it difficult to have a combination of (i) a centralized wage bargaining framework, (ii) limited regional labor mobility, and (iii) limited fiscal redistribution:

- If wage bargaining is centralized, then the wage response is restrained and adjustment to a regional shock should mainly occur through labor outflows from the region hit by a negative shock.

- If there is limited regional labor mobility, then a decentralized wage bargaining framework is needed to allow wages to adjust in response to regional shocks.

- If wage bargaining is centralized and regional labor mobility is limited, then regional unemployment disparities will emerge, increasing demands on fiscal redistribution.

Until recently, Finland's wage bargaining framework was highly centralized, which has constrained the adjustment of wages in response to regional labor demand shocks.

Figure 1 shows that Finland's wage bargaining system in 2014 was the second most centralized system in the EU-15. Tripartite agreements between trade unions, employers' organizations, and government covered the whole economy and determined labor conditions at the industry and company levels. The agreements were voluntary and included extension clauses, reaching virtually all wage earners and covering a wide range of labor conditions: salaries, taxation, pensions, unemployment benefits. The government often played a key role in these negotiations - at times through complementary policy actions - aiming to reconcile pay increases with productivity changes to maintain competitiveness. As a result, wages across industries and sectors have been historically compressed (Vainiomäki 2016; Böckerman and 
others 2017). In addition, wage compression coincided with relatively high minimum wages in some sectors, which accentuated downward wage rigidities. ${ }^{2}$

Wage rigidity shifts the burden of adjustment to regional labor mobility. Firms located in regions hit by a negative shock would not be able to adjust wages and would be forced to lay off staff. The newly unemployed would need to seek opportunities in other regions with more favorable economic environment. However, regional labor mobility may also be constrained due to various factors, such as large geographical distances across regions, housing cost differentials, infrastructure bottlenecks in remote areas, and relatively generous unemployment and social benefits. As a result, local shocks may lead to persistent unemployment disparities across regions and inflate structural unemployment at the national level. This, in turn, would increase demands on fiscal redistribution from prosperous regions to regions with persistently high unemployment.

This paper quantifies regional labor mobility in Finland, evaluates its impediments, and provides policy recommendations. We start by illustrating the stylized facts on regional labor mobility in Finland. Further, we employ conventional empirical approaches to quantify regional labor mobility and compare results with those of other countries. We also evaluate the impact of key drivers of labor mobility. Finally, we provide policy recommendations on how to improve resilience to regional shocks, including through regional labor mobility.

\section{LABor Mobility In FInland: Stylized FaCts}

We use data from regional administrative units to analyze developments in regional labor markets. Depending on data availability, we use data from three levels of regional aggregation: 5 NUTS 2 regions, 19 NUTS 3 regions, and 70 NUTS 4 regions. ${ }^{3}$ The NUTS classification defines minimum and maximum population thresholds for the size of the NUTS regions. Overall, the regional split at NUTS levels is sufficiently granular to study regional labor mobility.

The regional density of the Finnish population is quite heterogeneous. Total population is about $5.5 \mathrm{mln}$ and its distribution across 19 NUTS 3 regions ranges between 0.3 and $1.6 \mathrm{mln}$ (Figure 2). About quarter of the total population is concentrated in the South, where the main urban areas are located, including the capital Helsinki. Other regions, especially in the North, are characterized by less urbanization and are less populous despite larger geographical areas.

Unemployment and labor force participation rates vary widely across regions. In lowunemployment regions the unemployment rate fluctuated from 1 to 6 percent during

\footnotetext{
${ }^{2}$ In Finland, minimum wages are sector-specific and are determined by collective agreements. They also depend on work experience, individual characteristics, job complexity, and region.

${ }^{3}$ The NUTS (Nomenclature of Territorial Units for Statistics) classification has been developed by Eurostat. NUTS 2 regions are the largest in size, while NUTS 4 regions are the smallest.
} 
1987-2016 (Figure 3). By contrast, in high-unemployment regions the unemployment rates were consistently high, reaching 35 percent in 1996. Similarly, the labor force participation rates ranged from around 65 to 82 percent before the global financial crisis, with the range widening further in 2016 (Figure 4). The persistent variation in unemployment and participation rates could serve as an indirect evidence of regional disparities and lack of sufficient adjustment mechanisms.

Regional unemployment and labor force participation rates are highly persistent. Regions with high unemployment (participation) rates in 1987 tended to maintain high unemployment (participation) rates in 2016, and vice versa (Figures 5 and 6, respectively) ${ }^{4}$. Another way of analyzing unemployment persistence is to trace the dynamics of relative unemployment rankings of regions. The diagonal line in the transition matrix of unemployment quintiles (Table 1) represents the percentage of regions that remained in the same unemployment quintile over 1987-2016 and this percentage is particularly high for the top $1^{\text {st }}$ (86 percent) and bottom $5^{\text {th }}$ ( 57 percent) quintiles. In the meantime, no mobility was observed between extreme quintiles (e.g., between $5^{\text {th }}$ and $1^{\text {st }}$ quintiles). The presence of large regional discrepancies in unemployment and labor force participation rates and their persistence are indirect signs of limited labor mobility.

The in-migration and out-migration rates across regions are relatively modest. Gross migration for the whole country fluctuates around 2.3 percent for total population and around 2.6 percent for working age population (Figure 7). ${ }^{5}$ It exhibits some cyclicality, especially around the global financial crisis in 2008-09. To analyze gross labor mobility by regions, denote bilateral labor mobility $\left(M_{i j}\right)$ as the number of people that have migrated from region $i$ to region $j$. The in-migration rate can be estimated as the ratio of $M_{i j}$ and population in the destination region $j$, while the out-migration rate can be estimated as the ratio of $M_{i j}$ and population in the origin region $i$. The in-migration and out-migration rates across pairs of regions at NUTS 3 level are not high (Figures 8 and 9). The median is well below 0.1 percent over 2000-16. In each year, some pairs of regions did not have any in- or out-migration, while the maximum in- and out-migration rate hardly reached 0.4 percent. Also, the median regional in- and out-migration rates are relatively steady.

The in- and out-migration is geographically clustered. Regions with large population tend to have larger out-migration, with Uusimaa - which includes the capital Helsinki - being the largest donor of out-migrants (Figures [10]). This is not surprising, given that larger population means there is more people that could potentially relocate. However, regions with large population are also the ones that tend to attract more in-migrants, with Uusimaa

\footnotetext{
${ }^{4}$ A similar positive association emerges when using other time periods.

${ }^{5}$ While comparison with other countries is difficult in the absence of standardized cross-country datasets, the mobility is low when comparing to the U.S., where about 9 percent of the population moved between states and 18.6 percent of population moved between counties in 2000s (Molloy and others 2011).
} 
standing out again (Figures 11). This could be explained by the fact that regions with large population are typically urban areas and people tend to migrate from rural to urban areas. The net labor mobility (the difference between in- and out-migration) also varies across regions, with some Southern regions serving as net recipients of labor flows and some Northern regions serving as net donors (Figure 12). The main net recipient is again Uusimaa-the most populous urban region in Finland.

Regional variation in house prices has widened over time, while regional variation in wages has not changed much. Regional disparities in housing costs might become an impediment to regional labor mobility and warrant close inspection. From mid-1990s, regional house prices picked up and their regional dispersion has widened over time (Figure 13), which may have weighed on labor mobility. By contrast, the regional variation in real wages has remained relatively stable due to the centralized wage bargaining system (Figure 14).

\section{EMPIRICAL ANALYSIS}

We adopt two complementary empirical approaches to analyze regional labor mobility in Finland. The first one is an indirect approach popularized by Blanchard and Katz (1992). This approach does not require data on regional labor mobility and backs it out using regional information on total population, employment and labor force participation rates. It allows assessing the magnitude of regional labor mobility in response to a shock to a regional demand for labor. The second one is the direct approach based on the gravity framework widely used in the trade literature. It requires information on bilateral labor mobility across pairs of regions and allows analyzing the determinants of regional labor mobility.

\section{A. Blanchard and Katz (1992) Methodology}

\section{Blanchard and Katz (1992) propose a VAR framework to predict regional labor flows} following a labor demand shock. The approach relies on an identity linking changes in regional employment to changes in the employment rate, changes in the labor force participation rate, and changes in population, with the latter being interpreted as regional labor mobility (see Annex 1 for details). Using this methodology for the U.S. states, Blanchard and Katz (1992) found that regional mobility responds strongly to state-specific labor demand shocks. In the first year, a decrease in employment of 1 percent is reflected in an increase in the unemployment rate of 0.32 percentage points and a decrease in the participation rate of 0.17 percentage points. The remaining 0.51 percent is explained by the implied regional mobility. In the long-run, the impact on employment and labor force participation rates dissipates and the shock is almost fully absorbed by regional mobility. Likewise, Debelle and Vickery (1999) and Choy and others (2002) report regional labor mobility is a key adjustment mechanism in Australia and New Zealand, respectively. By contrast, Decressin and Fatas (1995) find little evidence of regional labor mobility in Europe. Instead, the adjustment to region-specific shocks tends to occur mainly via labor force participation rates. For instance, 
in the first year following the 1 percent shock, 0.78 percent of the impact is borne by workers dropping out of the labor force compared to only 0.17 percent in the U.S.

Using the Blanchard and Katz (1992) methodology, we find a more modest response of regional labor mobility in Finland compared to the U.S. In Finland, employment starts recovering immediately after the 1 percent adverse shock. In the first year following the shock, 0.7 percent of the impact is borne by the increase in the unemployment rate and 0.17 percent is borne by the decline in the participation rate, with the remaining 0.13 percent attributed to regional mobility (Figure 15). Over time, the recovery in employment continues and about half of the lost employment recovers by the tenth year. The impact on unemployment and participation rates dissipates over time, while the impact on out-migration gradually builds up reaching slightly below 0.4 percent by the tenth year. ${ }^{6}$ In the U.S. (Figure 16) the impact on the unemployment rate is less pronounced compared to Finland, peaking at 0.3 percent in the second year and dissipating quickly thereafter. Similarly, the short-run impact on out-migration is larger and peaks at slightly about 0.6 percent in the fifth year, suggesting a stronger role of regional mobility in the U.S. compared to Finland. Nevertheless, these results should be interpreted with caution given the different characteristics of these two countries in terms of the population size, geography, and the number of regions.

\section{The labor mobility response in Finland is lower also relative to most of the EU peers.} Unfortunately, for EU countries harmonized regional data is not available at the NUTS 3 level, so we have used NUTS 2 level data. In Finland, the labor mobility response at the NUTS 2 level was found to be close to zero-much lower relative to the response at the NUTS 3 level (Figure 17). This is not surprising given that NUTS 2 level implies a higher aggregation compared to the NUTS 3 level. In other words, NUTS 2 level data does not capture regional flows across NUTS 3 regions located within NUTS 2 areas. The main takeaway from this analysis is that the labor mobility response Finland is one of the smallest among EU comparators, including Austria, Belgium, France, Germany, Italy, the Netherlands, and Spain. Nevertheless, this result should be interpreted with caution since the number of NUTS 2 regions varies significantly across countries: from 5 in Finland to 38 in Germany.

\section{B. Gravity Model}

The gravity model ascertains factors that underlie decisions to migrate across regions. It recognizes that labor mobility is inherently a spatial phenomenon and regional differences in wages, employment opportunities, and amenities, among others, could encourage individuals to change their residence to realize utility gains (see Annex [2] for details). Like in physics, there are gravitational forces that underpin regional mobility. One is the demographic force, suggesting that regional labor mobility is proportional to the size of population in the origin

\footnotetext{
${ }^{6}$ The Blanchard and Katz (1992) methodology relies on the assumption that the labor force participation rate is a stationary variable. We tested the stationarity of the labor force participation rate variable using the Im-PesaranShin panel unit root test. The null hypothesis of a unit root in all series is strongly rejected ( $p$-value $=0.0007$ ).
} 
and destination. Another is the distance force, suggesting that the regional labor mobility is inversely related to the geographical distance between the origin and destination as longer distance implies larger relocation costs. In the literature, the baseline gravity model is frequently modified to include other regional factors that could drive regional mobility, such as unemployment rates, wages, and house prices in the origin and destination (see Greenwood 1997; Greenwood 2005 for a survey).

Several studies have applied the gravity model to analyze migration flows across countries. For a sample of 12 euro area countries over the period 1992-2011, Arpaia and others (2018) find that unemployment is a strong predictor of migration flows. Common language and pre-existing migrant community are also positively associated with migration, while distance and absence of common borders have adverse relationship with migration. Beine and others (2018) use a sample of 24 destination and 30 origin OECD countries for the period 1980-2010 and find that business cycles and employment rates at the destination affect the intensity of migration. Also, they find that the Schengen Agreement and the euro significantly raised the international mobility of workers. Finally, Marques (2010) and Pytliková (2014) study migration from "new" to "old” EU Member States. They also report significant effects of distance, income differentials, common language, and pre-existing migrant community. Another result is that tightening of migration policies has an impact only with a lag.

Regional labor mobility in Finland has been analyzed using micro data. Böckerman and others (2017) and Maczulskij and others (2018) use matched employer-employee data to analyze the response of workers to plant closure. They find that job displacement increases the probability of regional migration by about 70 percent. However, people do not make decisions solely on short-term economic incentives and take into account also housing related factors and the social environment of the regions. Job displacement also has an immediate negative impact on the earnings of displaced workers.

We adopt the gravity model to analyze regional labor mobility across pairs of regions in Finland. The advantage of using data on labor mobility within a country is that it allows focusing on a narrower range of determinants, since some impediments to labor mobility present in a cross-country context are not relevant (e.g., language barriers, borders). Column (1) of Table 2 presents estimations results for the total sample. Most of the coefficients are significant and have the expected signs: ${ }^{7}$

\footnotetext{
${ }^{7}$ The decision to migrate may be based on observed changes in dependent variables, so we checked the robustness to the lag structure of the dependent variables - the results are qualitatively similar.
} 
- Gravity forces work. Geographical distance has a negative effect on labor mobility: a 1 percent increase in distance reduces mobility by about 1.45 percent. ${ }^{8}$ Moreover, regional mobility tends to be stronger across more populous regions: a 1 percent increase in the population of the origin region increases out-migration by about 1.34 percent, while a 1 percent increase of population in the destination region increases in-migration by 0.58 percent.

- $\quad G D P$ per capita matters. Labor tends to flow out from poorer regions into richer regions. A 1 percent increase in real GDP per capita in the origin region decreases outmigration by 0.17 percent, while a 1 percent increase in real GDP per capita in the destination region increases in-migration by 0.28 percent.

- Unemployment matters. Labor tends to flow out from regions with relatively higher unemployment to regions with relatively lower unemployment. A 1 percent increase in unemployment in the origin region increases out-migration by 0.83 percent, while a 1 percent increase in unemployment in the destination region decreases in-migration by 0.86 percent. This is consistent with the results of Arpaia et al. (2018).

- Wage differentials do not matter. Wage differences across regions in real terms do not have a significant impact on labor mobility. This may be explained by the centralized wage bargaining system that resulted in relatively compressed wage differentials in Finland (Vainiomäki 2016).

- Housing costs matter. Labor tends to flow out from regions with relatively higher house prices to regions with relatively lower house prices. A 1 percent increase in real house prices in the origin region is estimated to increase out-migration by 0.29 percent, while a 1 percent increase in real house prices in the destination region would decrease inmigration by 0.24 percent.

The model explains 91 percent of variation in migration as shown by the R-squared. Without fixed effects, the model explains 83 percent of the variation suggesting that observable control variables play important role in explaining the variation in labor mobility. The exogenous observable variable - distance - explains 23 percent of the variation, while remaining variables, some of which can be influenced by policies, explain 60 percent of the variation.

Columns (2) and (3) of Table 2 present the results of separate regressions for males and females. The results on the determinants of regional labor mobility are broadly consistent across

\footnotetext{
${ }^{8}$ Using the square of distance produces similar results, but the coefficient of the distance variable is twice smaller given the logarithmic transformation.
} 
genders. Columns (4)-(6) use labor mobility of the working age population (15-64 years) as a dependent variable. The results are qualitatively similar to those for the total population. ${ }^{9}$

\section{Conclusions and Policy Recommendations}

This paper finds that regional labor mobility in Finland is relatively limited compared to the U.S. and to $\mathbf{E U}$ peers. Limited regional mobility suggests that regional shocks may have contributed to persistent divergence of regional unemployment rates. This in turn contributes to fiscal redistribution from regions with low unemployment to regions with high unemployment.

Several impediments appear to constrain regional labor mobility in Finland. The gravity analysis suggests that regional labor mobility is adversely affected by the geographical distance across regions, and positively affected by the size of the population in the origin and destination regions. Also, there is evidence that labor moves out from regions with relatively low GDP per capita, high unemployment and house prices toward regions with relatively high GDP per capita, low unemployment, and low house prices. Interestingly, real wages in the origin and destination regions were not found to have a significant impact on regional labor mobility. This could be because relatively low variation of wages across regions due to centralized wage bargaining does not provide sufficient incentives for mobility.

\section{Limited regional labor mobility could contribute to persistent unemployment differentials across regions and inflate structural unemployment. Regional disparities could widen in response to local shocks in the presence of impediments to labor mobility. Lack of wage flexibility could further complicate the adjustment to regional shocks. Wider disparities could inflate structural unemployment and lead to increased demands on fiscal redistribution across regions.}

Targeted policies could help incentivize more regional labor mobility to contribute to the efficiency of job matching and reduce the fiscal redistribution burden. These policies could be formalized within the "challenging trinity" framework mentioned above and should take into account potential tradeoffs between equity and efficiency (Moretti 2011). For instance, more regional wage flexibility could provide further incentives for regional labor mobility. The decentralization effort as part of the Competitiveness Pact in 2016 is a step in the right direction, but there is scope for enhancing decentralization further at the local and firm level. In addition, the generosity of the unemployment insurance system and social benefits in general could be revisited further (OECD 2018), which in combination with strengthening of active labor market policies would encourage job search and reduce unemployment differentials across regions. Finally, improving infrastructure and

\footnotetext{
${ }^{9}$ The correlation between total population and working age population mobility rates is very high and close to 1 for the total sample and for 5-year rolling window subsamples. The scatterplot between the two also suggests a very close association. These results are available upon request.
} 
transportation, especially around vibrant urban areas, could encourage commuting and reduce pressures on urban housing demand (EC 2018). Reduction of the mortgage interest deductibility further beyond the current timetable could reduce the home ownership bias and make rental market more vibrant (IMF 2014). 


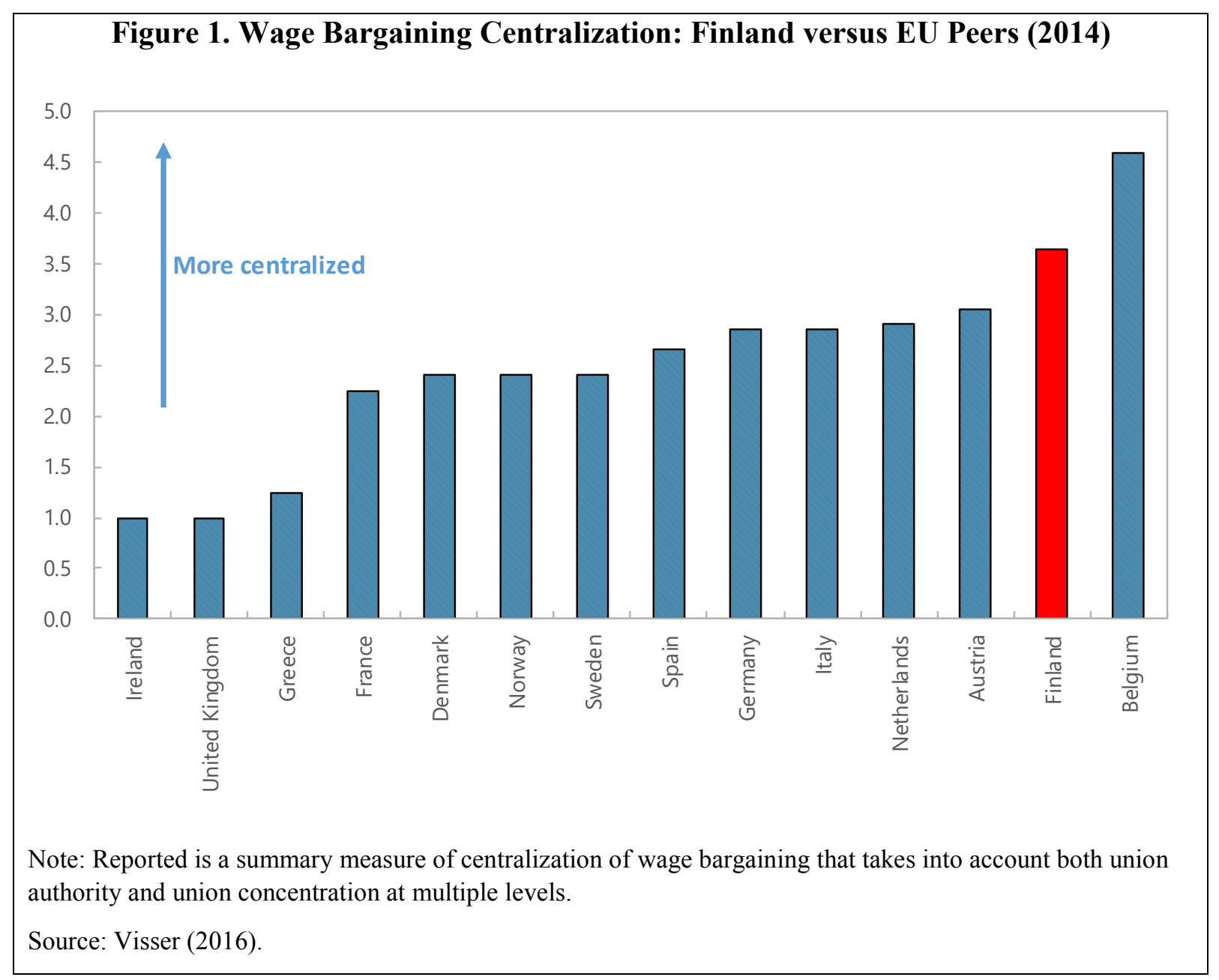


Figure 2. Demographic Geography of Finnish Regions

Population

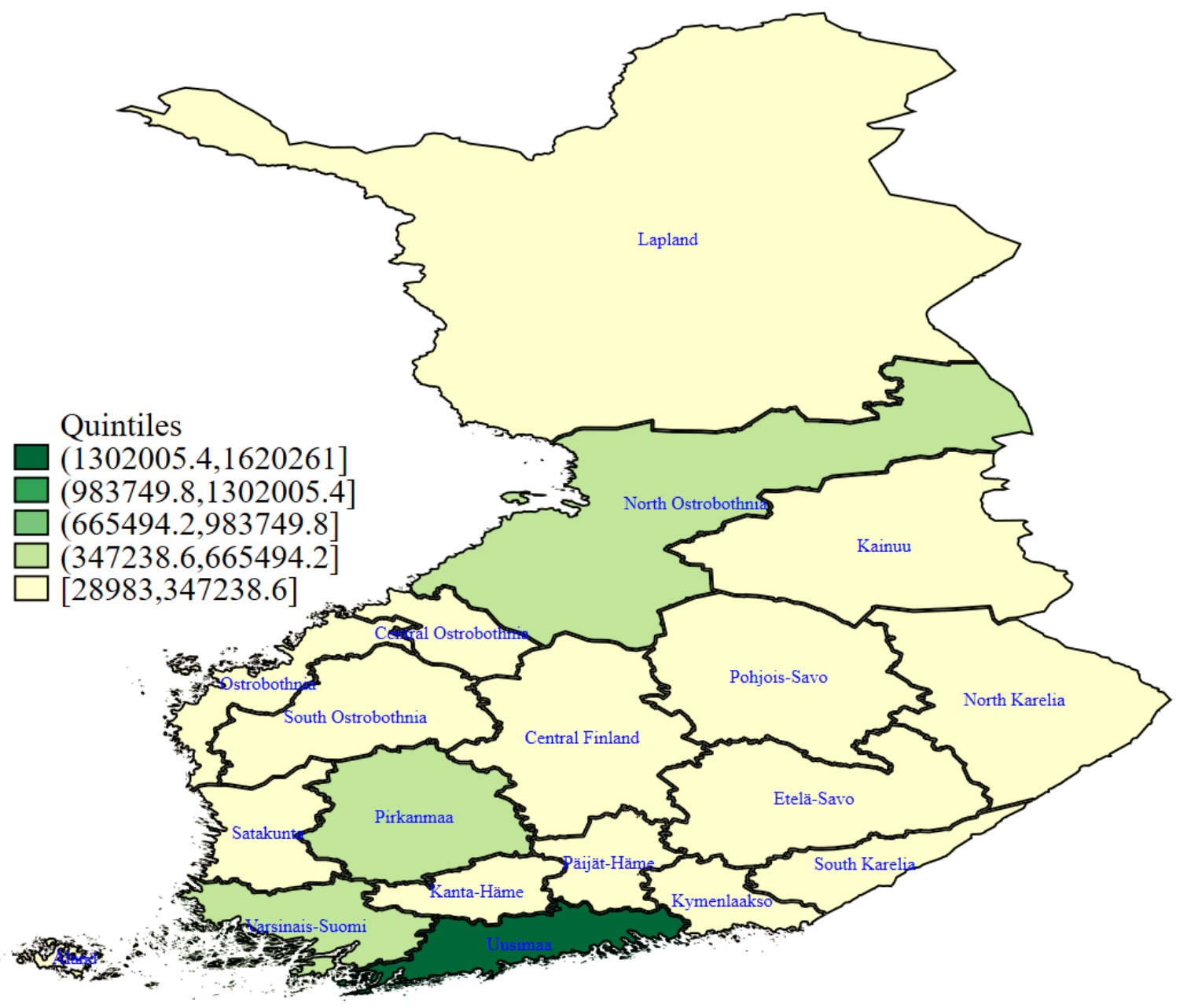

Source: Eurostat and IMF Staff calculations.

Note: The sample includes 19 NUTS 3 regions in 2016. The color coding reflects the quintiles of the respective regional variable. 


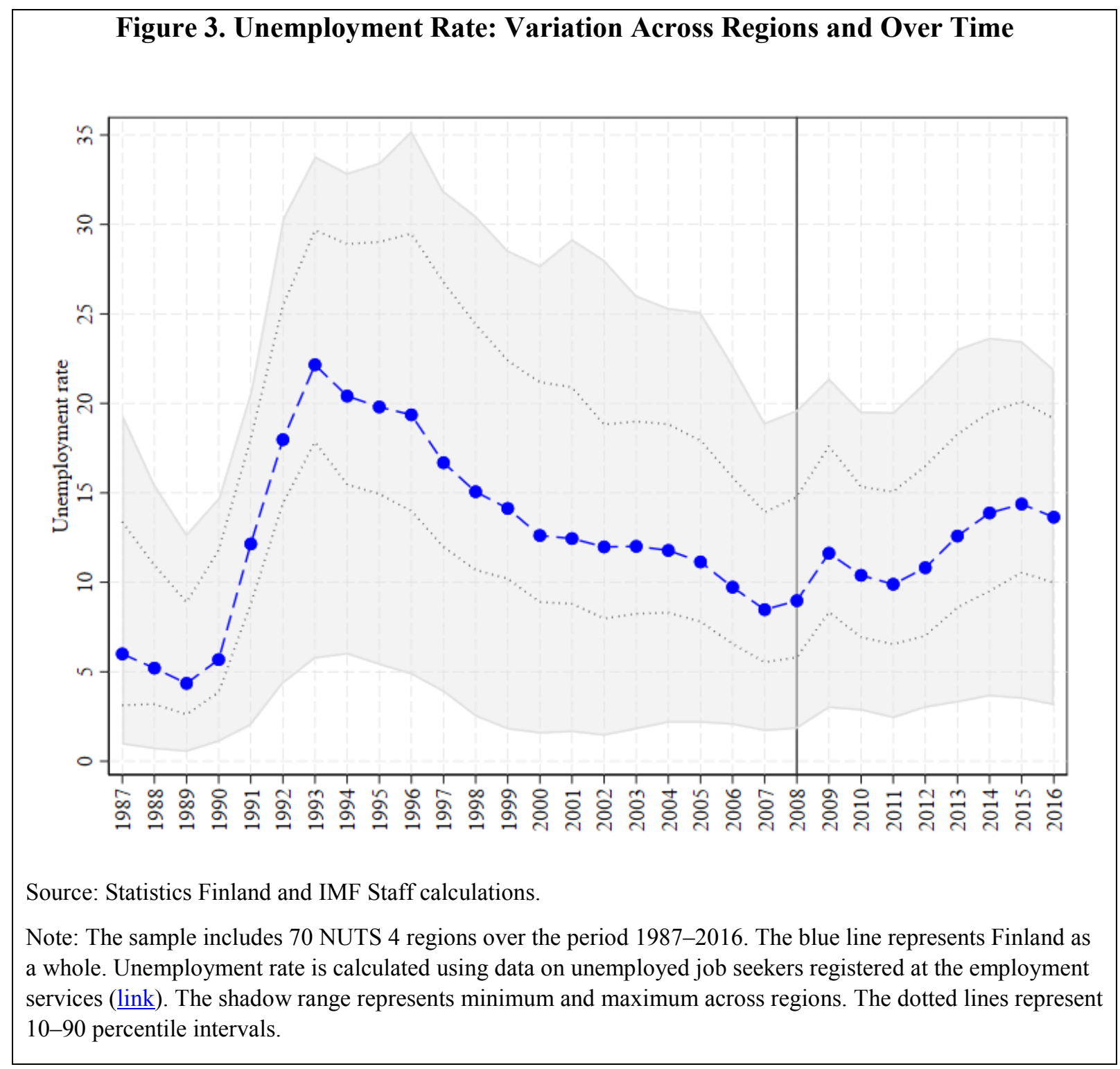


Figure 4. Labor Force Participation Rate: Variation Across Regions and Over Time

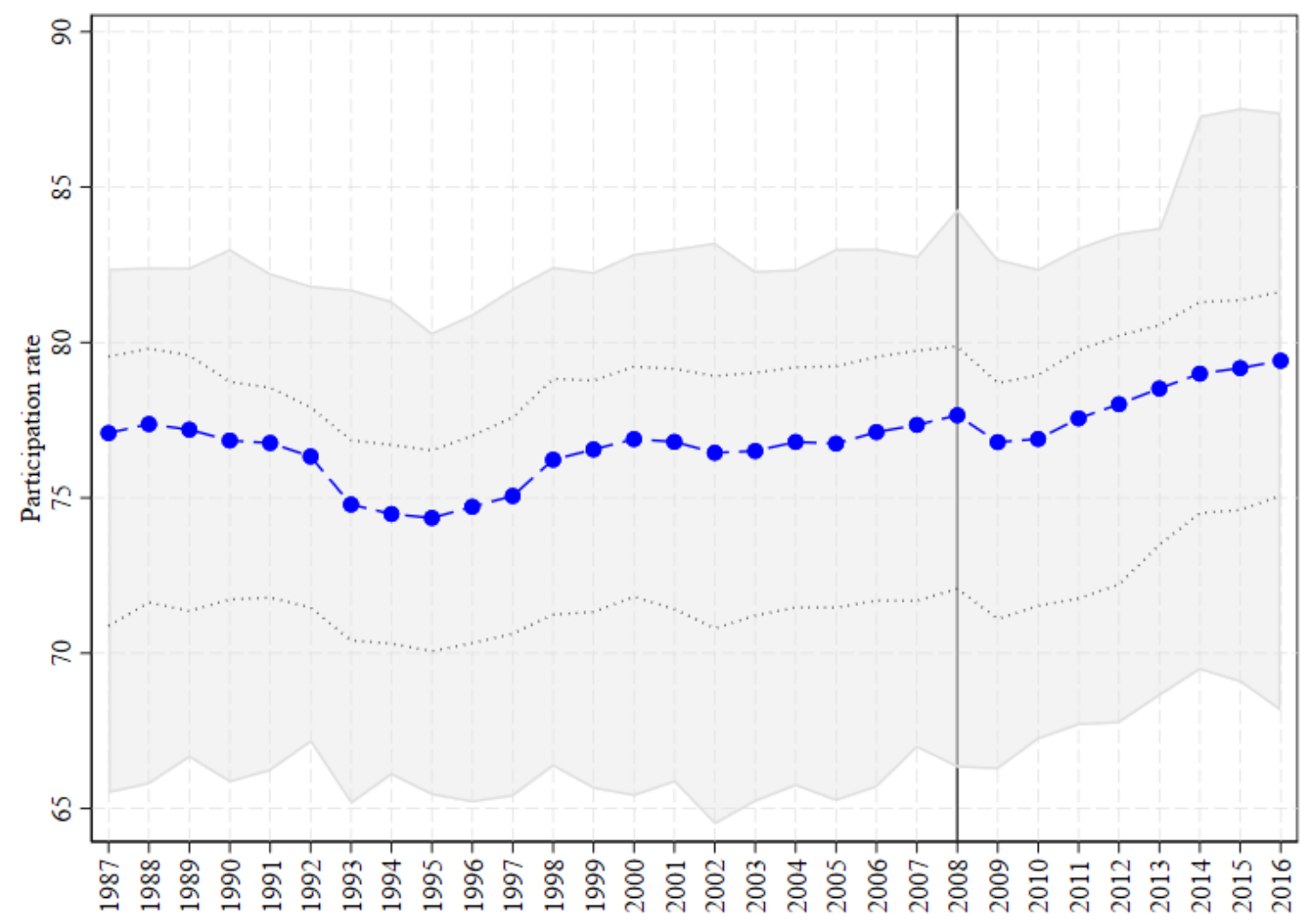

Source: Statistics Finland and IMF Staff calculations.

Note: The sample includes 70 NUTS 4 regions over the period 1987-2016. The blue line represents Finland as a whole. The shadow range represents minimum and maximum across regions. The dotted lines represent $10-$ 90 percentile intervals. 


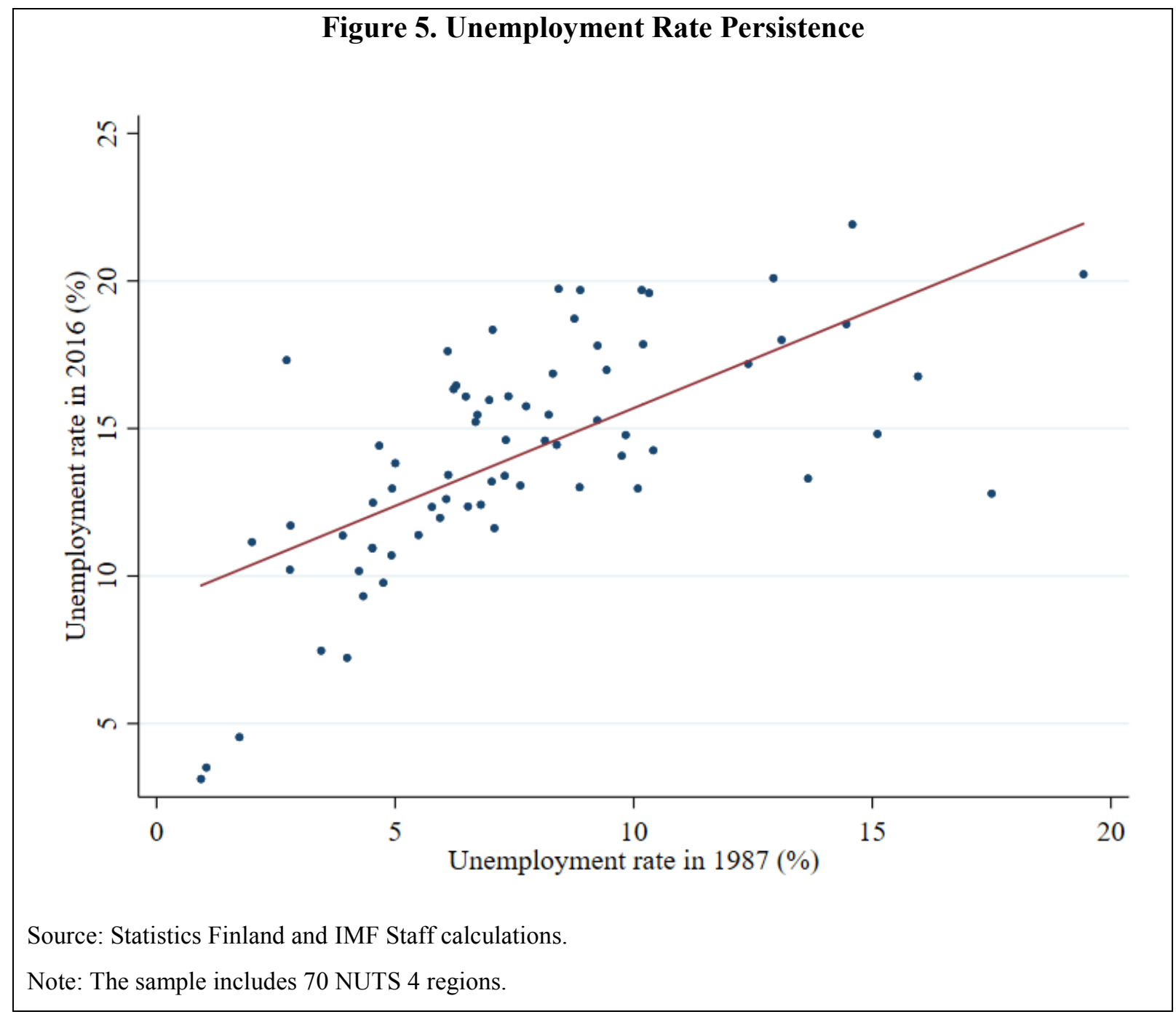

CInternational Monetary Fund. Not for Redistribution 


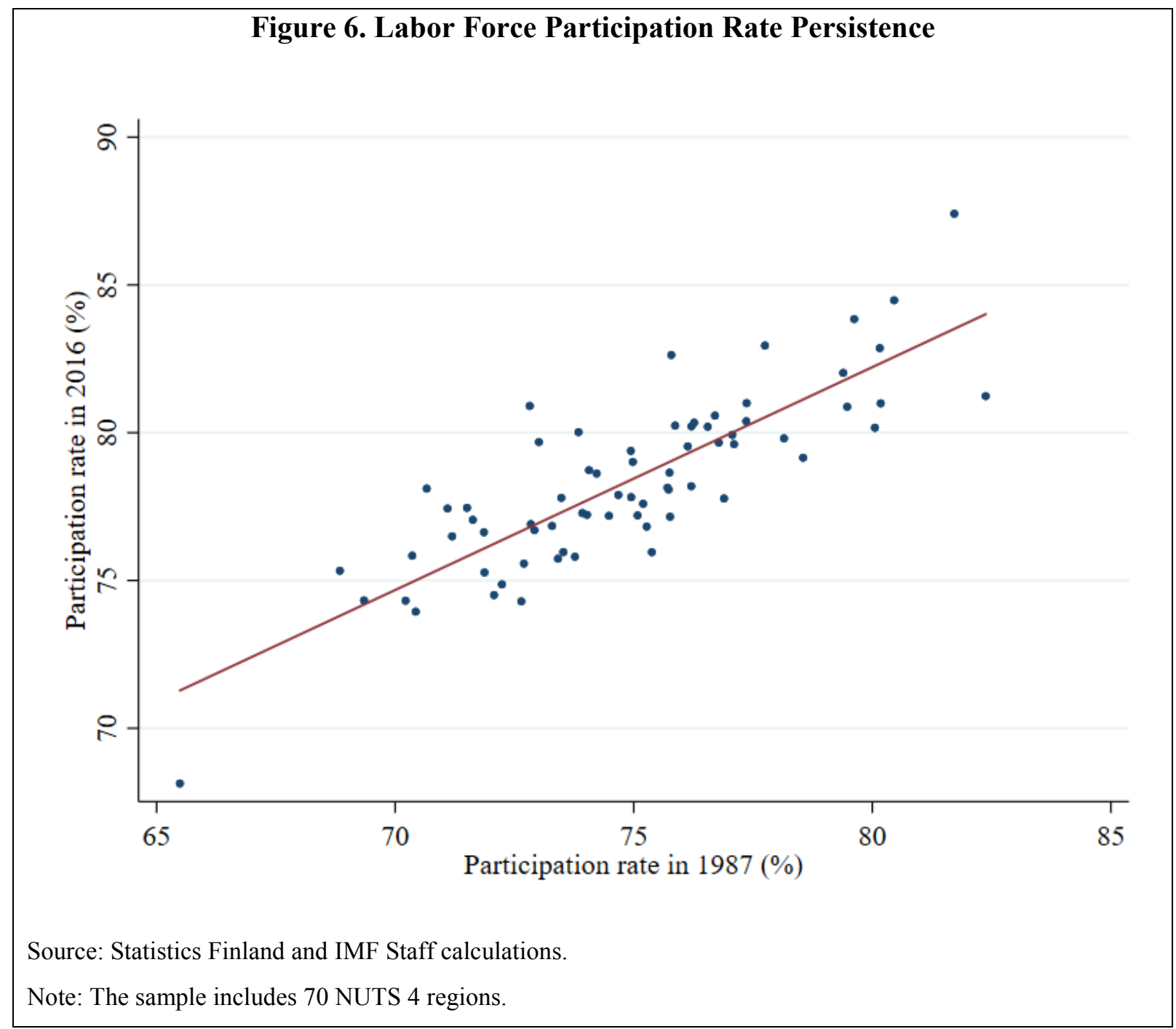

CInternational Monetary Fund. Not for Redistribution 


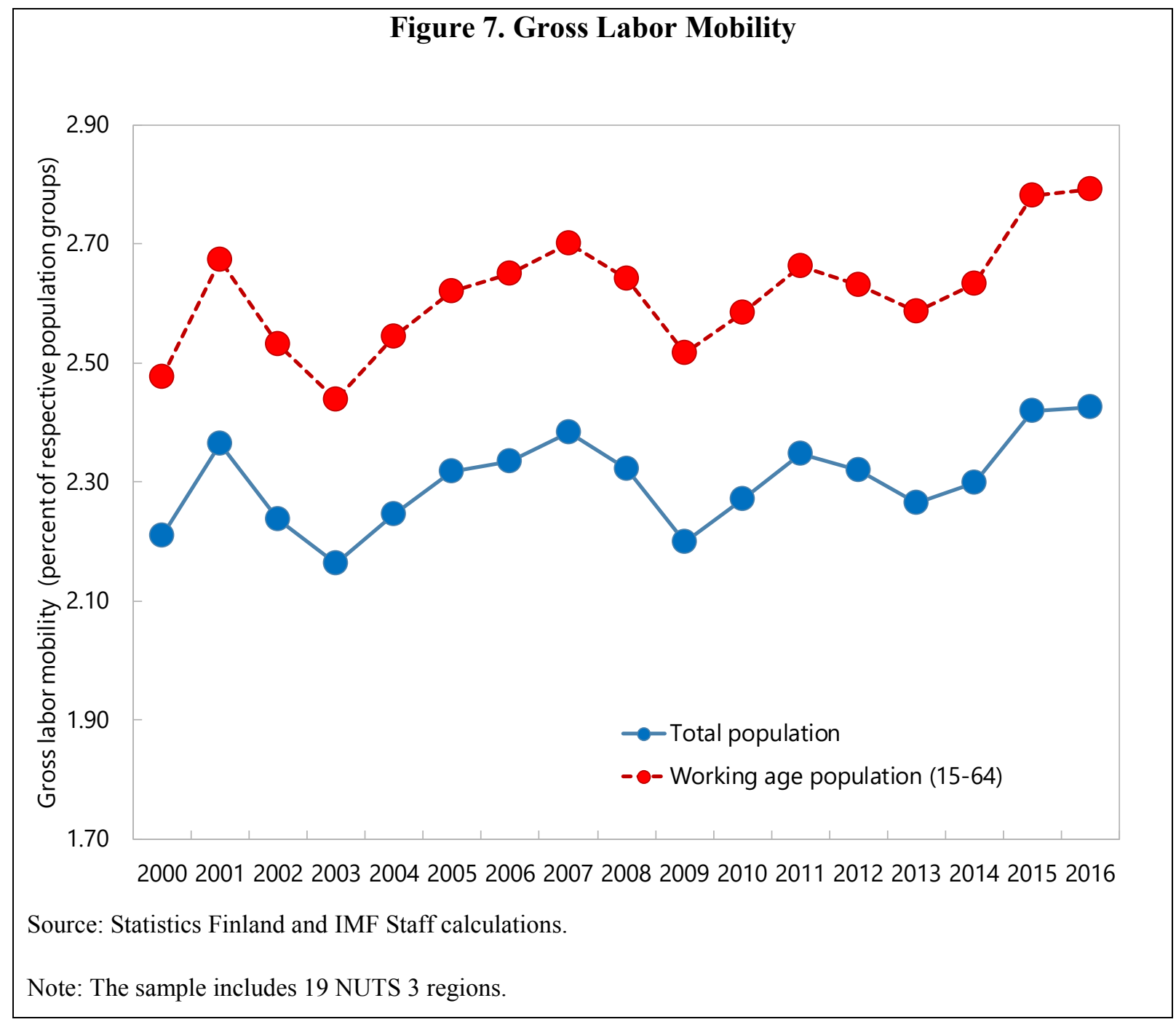


Figure 8. Out-Migration rate: Variation Across Regions and Over Time

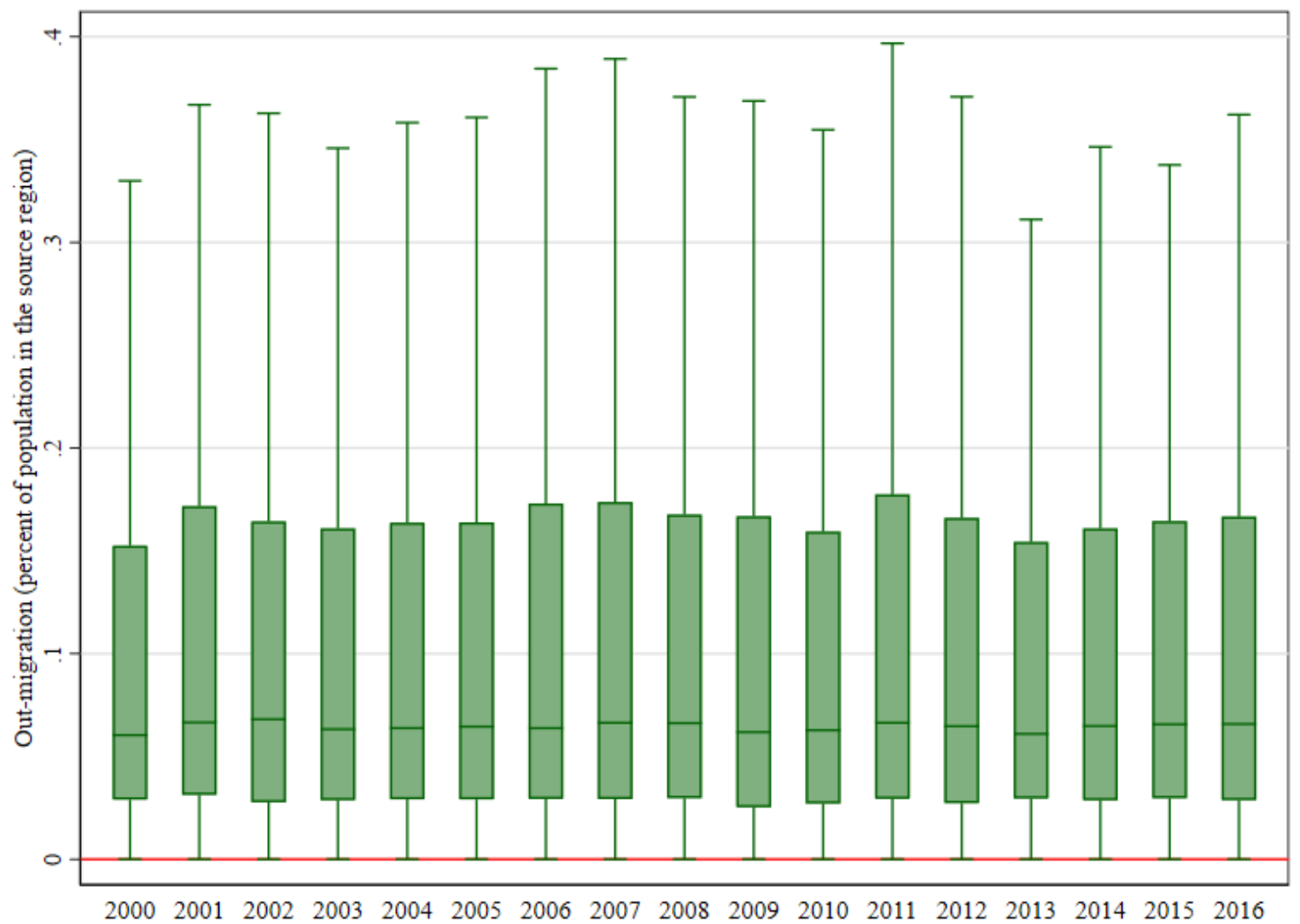

Source: Statistics Finland and IMF Staff calculations.

Note: The sample includes 19 NUTS 3 regions over the period 2000-2016. Reported are ranges of in-migration rates across all regional pairs. The line splitting the box represents the median, the edges of the box represent the 25 and 75 percentiles, and the whiskers represent minimum and maximum. 


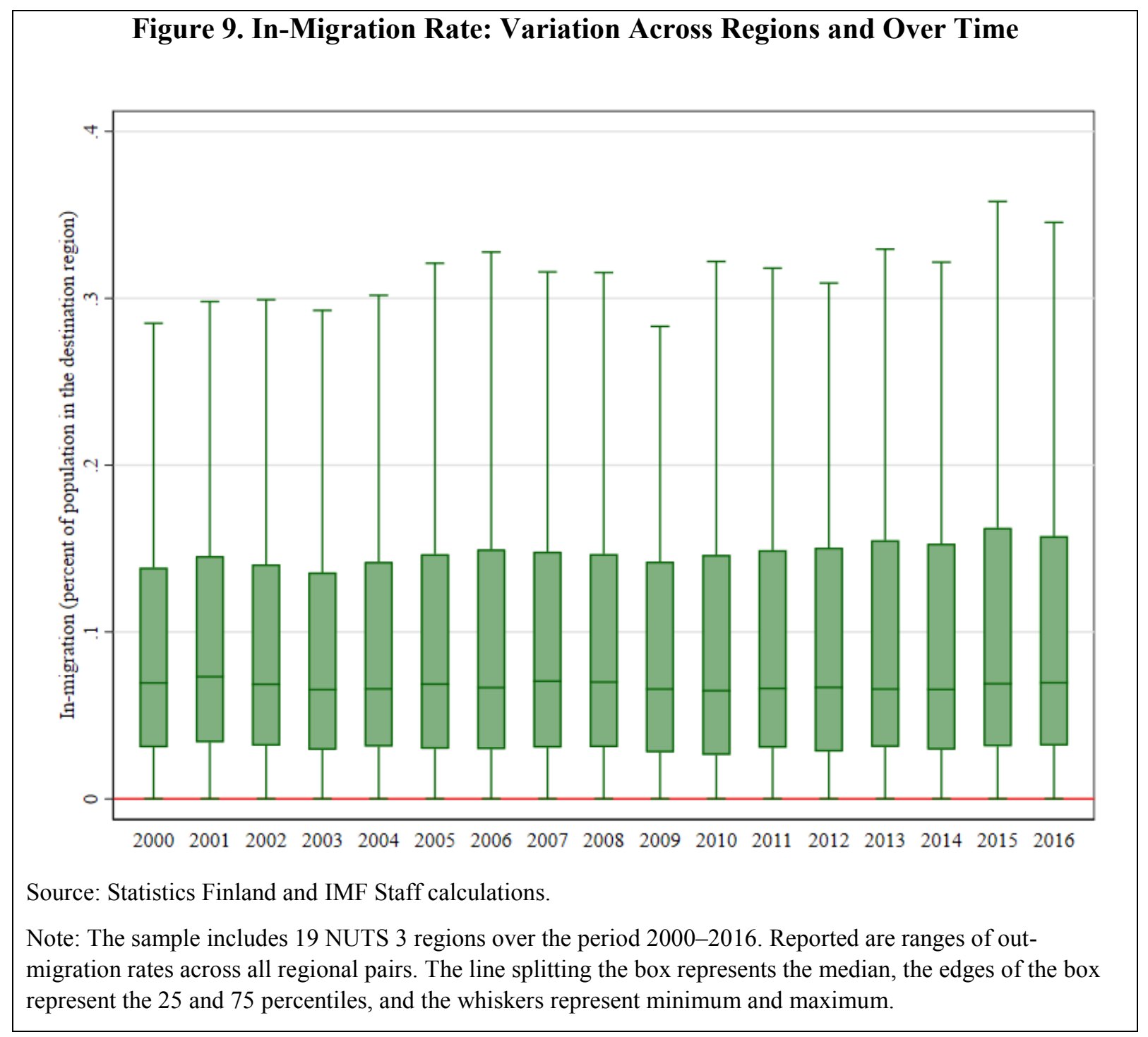


Figure 10. Network of Out-Migration Flows Across Pairs of Regions

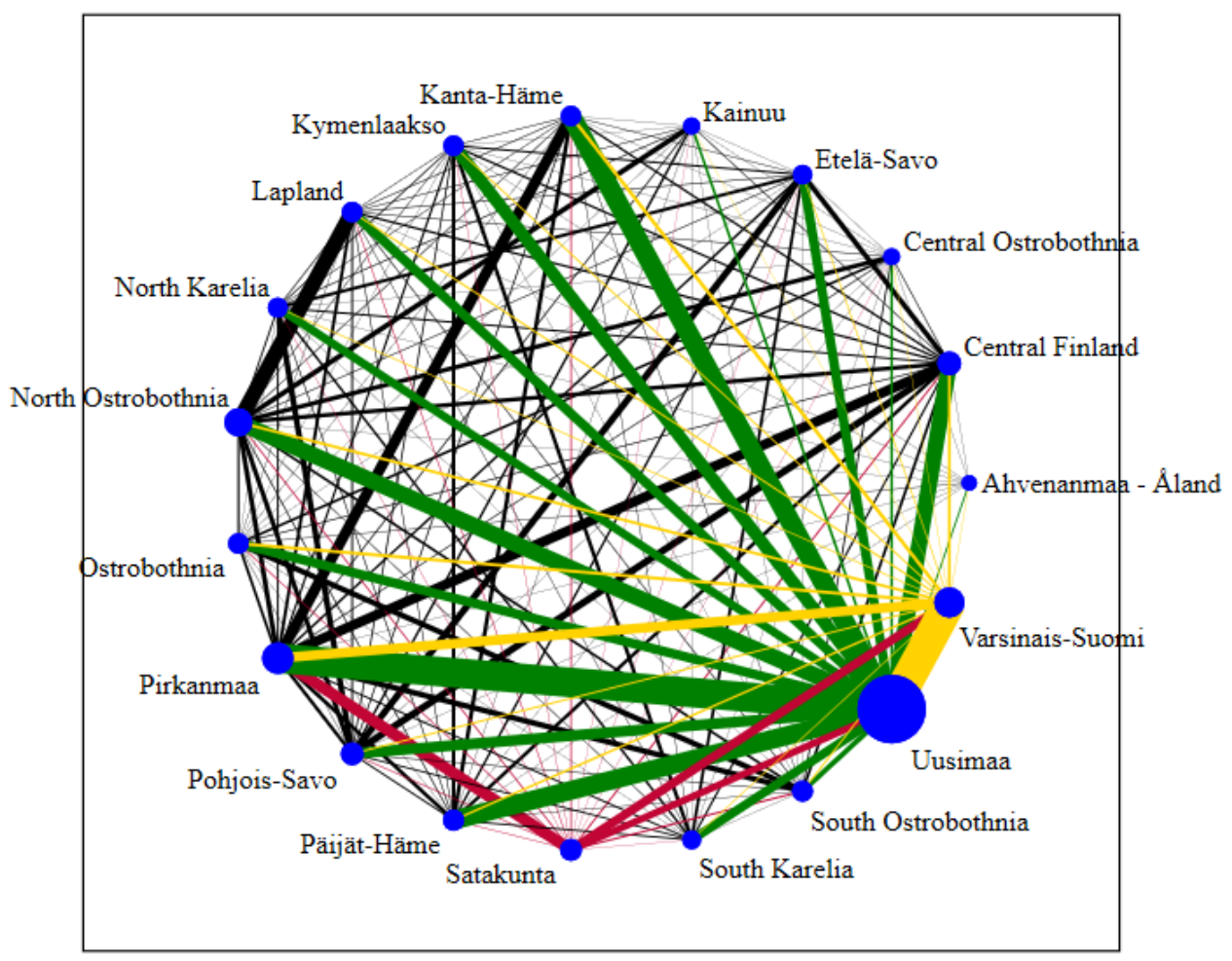

Source: Statistics Finland and IMF Staff calculations.

Note: The sample includes 19 NUTS 3 regions for 2016. The size of the nodes is proportional to the population size. The width of the edges is proportional to the size of the out-migration flow. The colors are allocated randomly. 
Figure 11. Network of In-Migration Flows Across Pairs of Regions

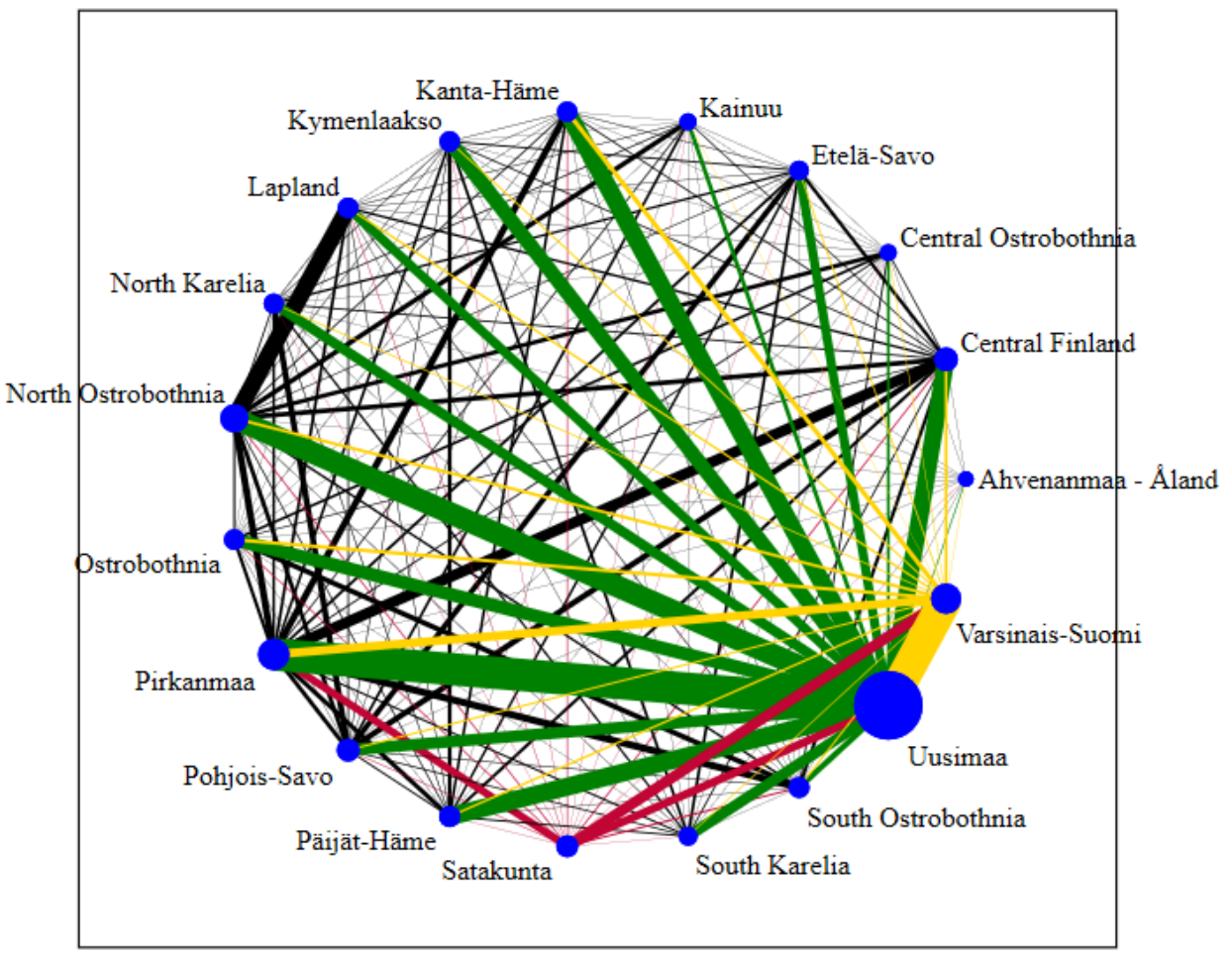

Source: Statistics Finland and IMF Staff calculations.

Note: The sample includes 19 NUTS 3 regions for 2016. The size of the nodes is proportional to the population size. The width of the edges is proportional to the size of the out-migration flow. The colors are allocated randomly. 


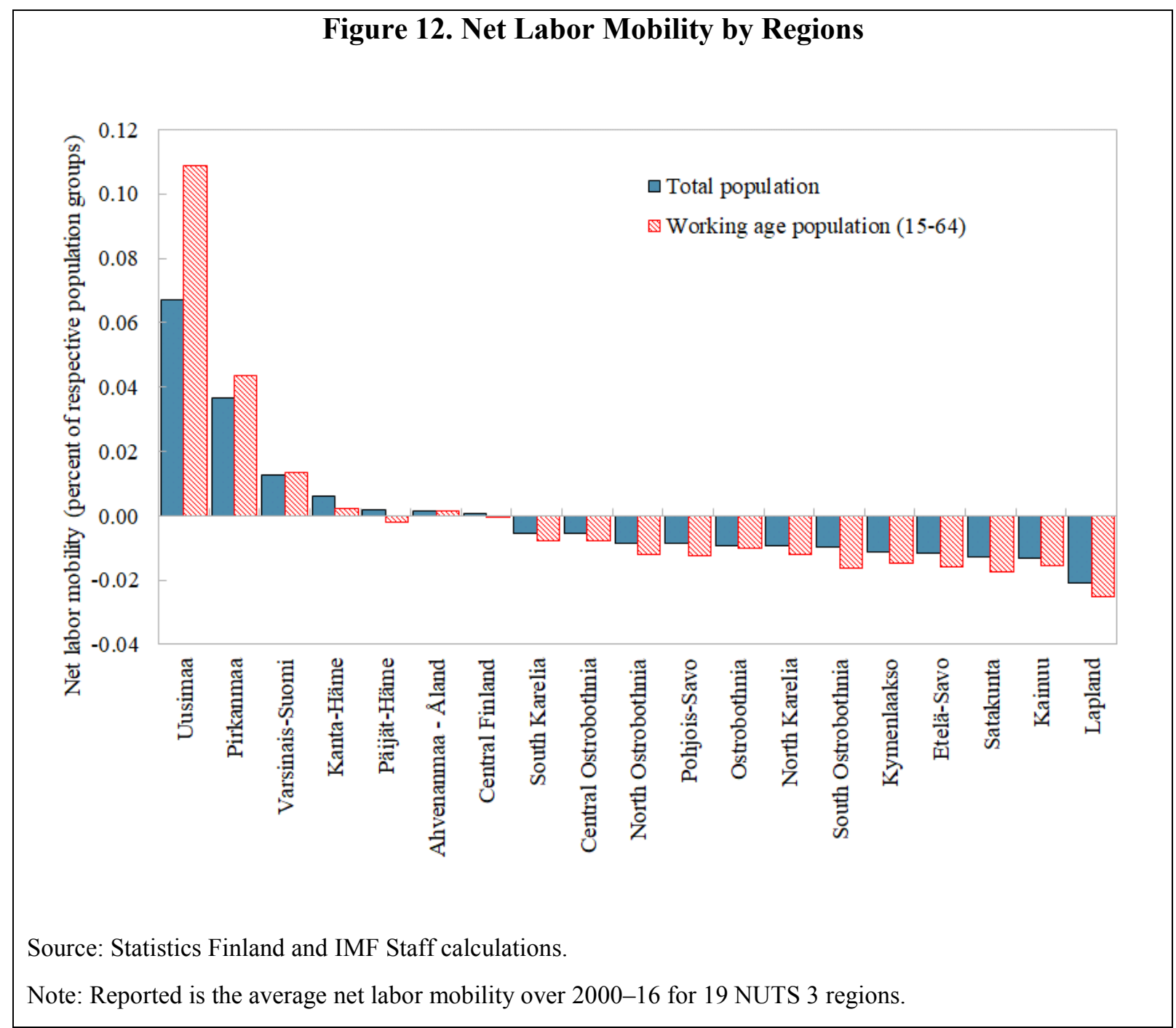




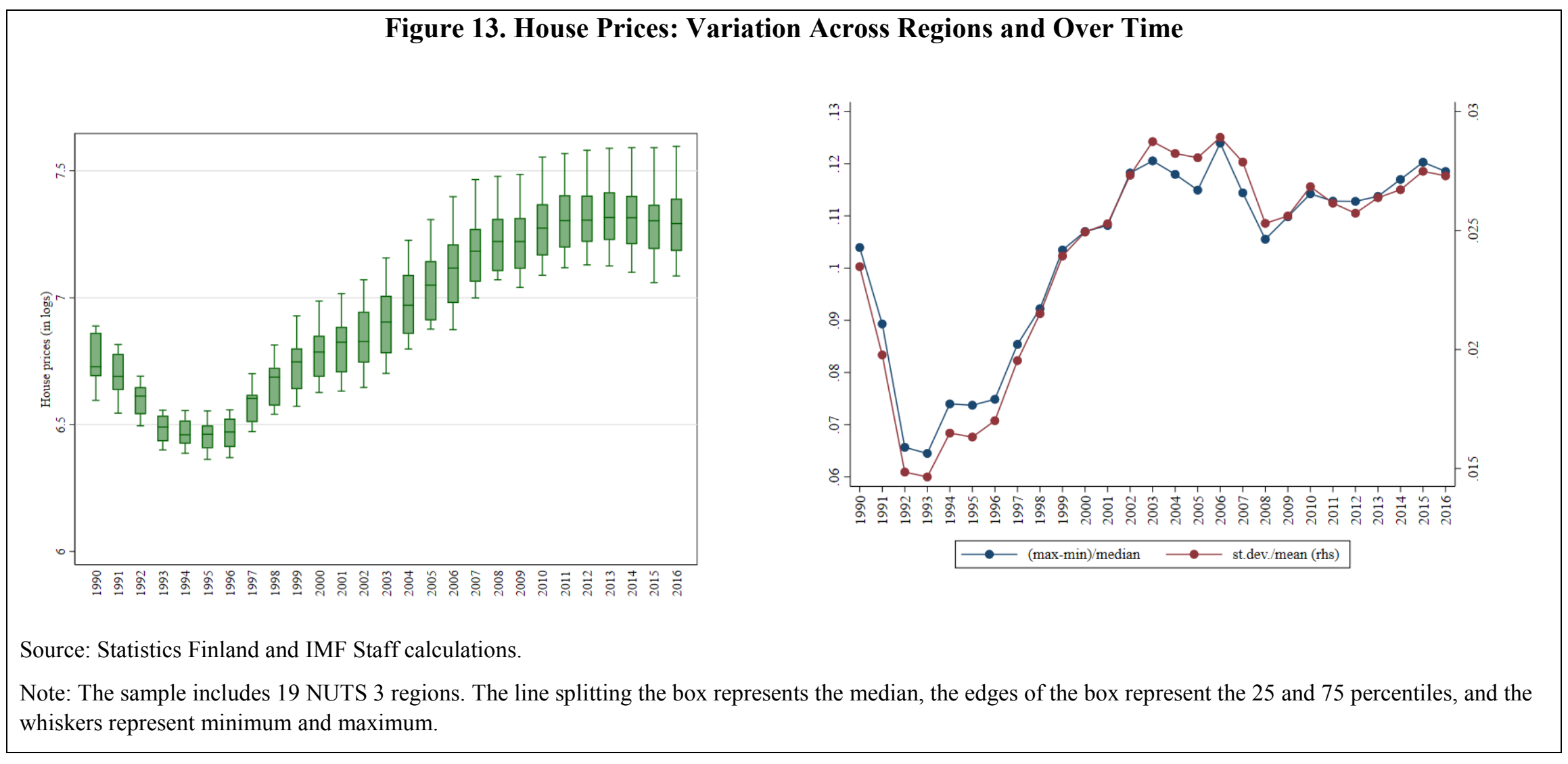




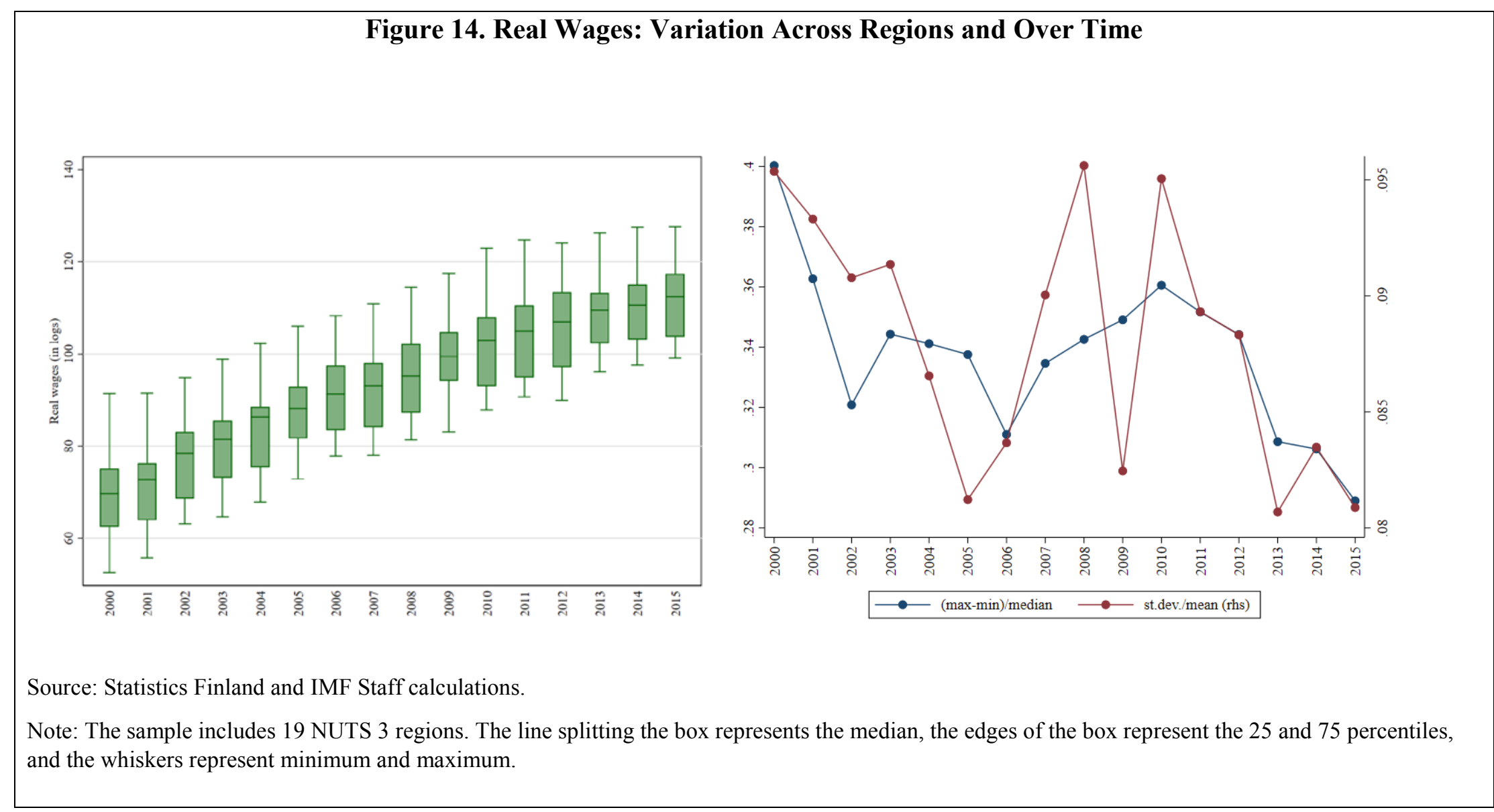


Figure 15. Finland: Blanchard and Katz (1992) Model Replication

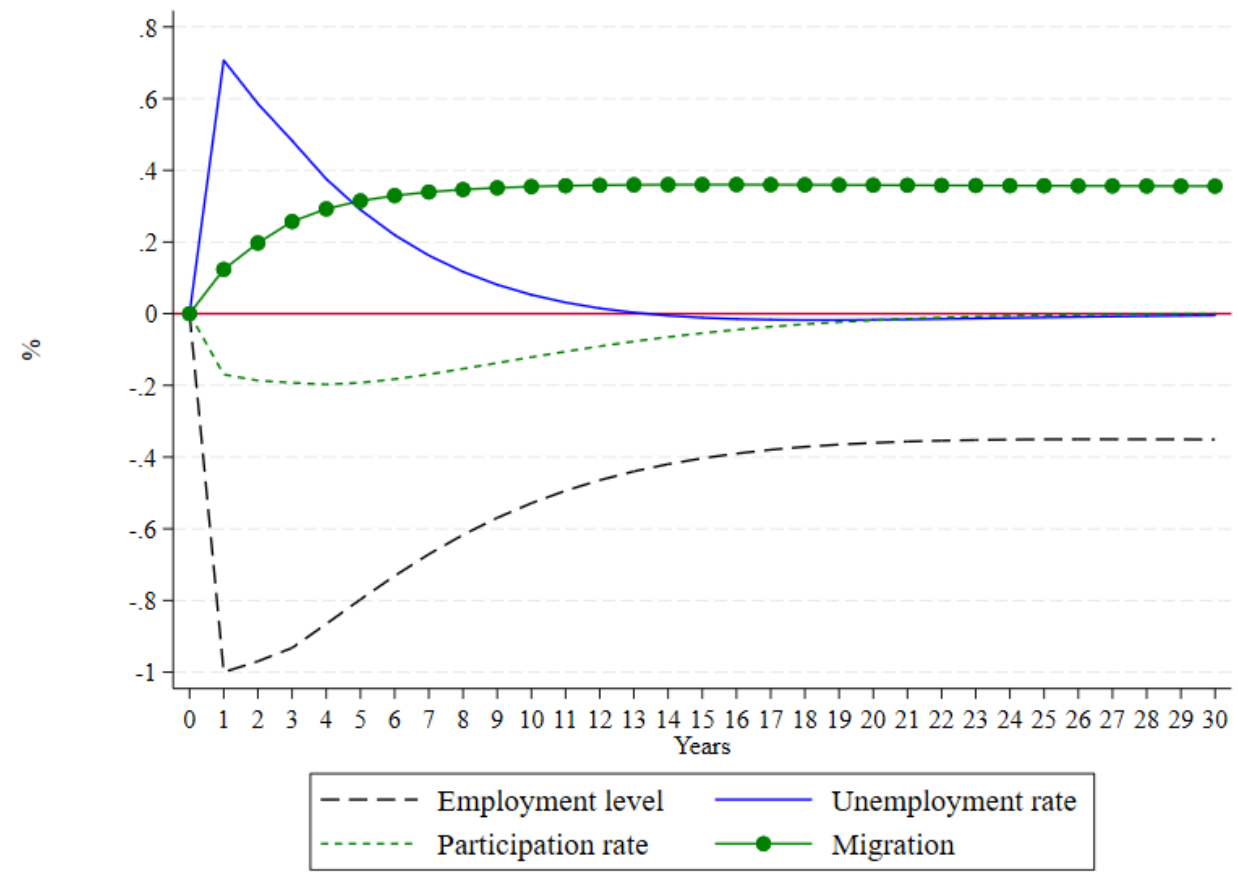

Source: Statistics Finland and IMF Staff calculations.

Note: Estimations are performed using the Blanchard and Katz (1992) VAR model with 2 lags. The sample includes 70 NUTS 4 regions in Finland for the period 1987-2016. 
Figure 16. USA: Blanchard and Katz (1992) Model Replication

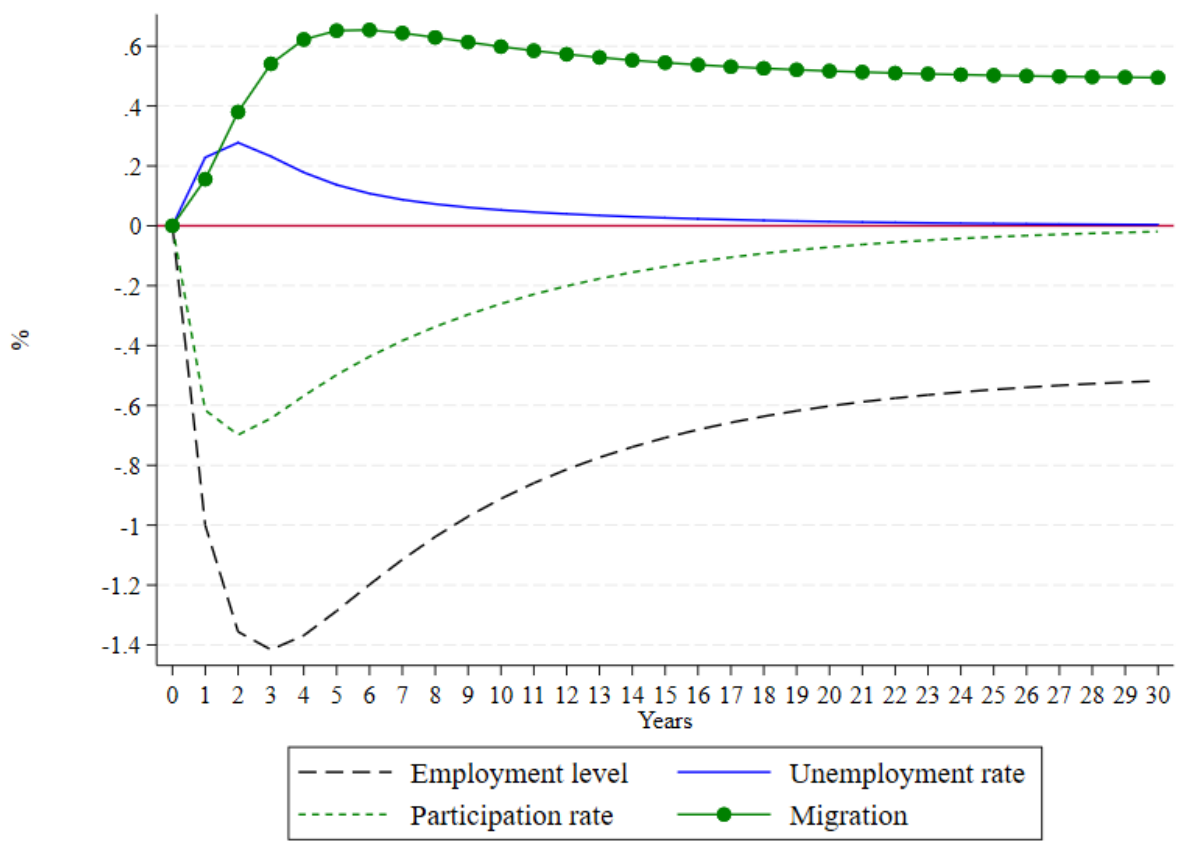

Source: Greenaway-McGrevy and Hood (2016) and IMF Staff calculations.

Note: Estimations are performed using the Blanchard and Katz (1992) VAR model with 2 lags. The sample includes 325 Metropolitan Statistical Areas (MSAs) in the U.S. for the period 1990-2012. 
Figure 17. Blanchard and Katz (1992) Model Replication:

Labor Mobility Response in Finland Versus EU Countries

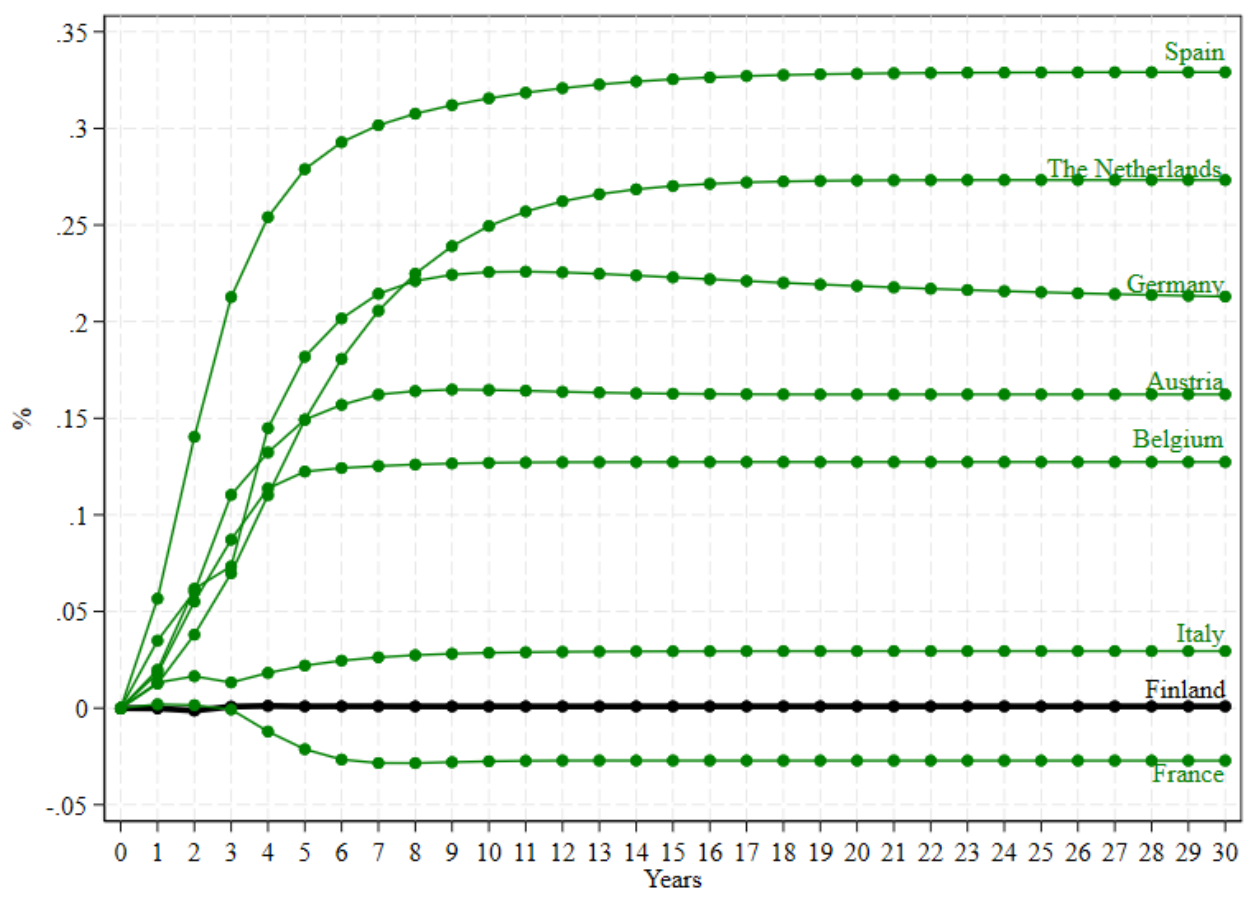

Source: Eurostat and IMF Staff calculations.

Note: Estimations are performed using the Blanchard and Katz (1992) VAR model with 2 lags. The sample includes NUTS 2 regions for the period 2000-16. 


\begin{tabular}{|c|c|c|c|c|c|c|}
\hline & & \multicolumn{5}{|c|}{ Quintile in 2016} \\
\hline & & 1 & 2 & 3 & 4 & 5 \\
\hline \multirow{10}{*}{ 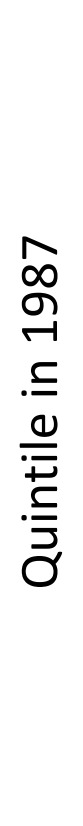 } & 1 & 0.86 & 0.07 & 0.00 & 0.07 & 0.00 \\
\hline & & (12) & (1) & (0) & (1) & (0) \\
\hline & 2 & 0.14 & 0.43 & 0.21 & 0.14 & 0.07 \\
\hline & & $(2)$ & (6) & (3) & (2) & (1) \\
\hline & 3 & 0.00 & 0.29 & 0.29 & 0.36 & 0.07 \\
\hline & & (0) & (4) & (4) & (5) & (1) \\
\hline & 4 & 0.00 & 0.14 & 0.29 & 0.29 & 0.29 \\
\hline & & (0) & (2) & (4) & (4) & (4) \\
\hline & 5 & 0.00 & 0.07 & 0.21 & 0.14 & 0.57 \\
\hline & & (0) & (1) & (3) & $(2)$ & (8) \\
\hline
\end{tabular}

Source: Statistics Finland and IMF Staff calculations.

Note: The sample includes 70 NUTS 4 regions. Reported are transition probabilities. The numbers of regions are presented in parentheses. 


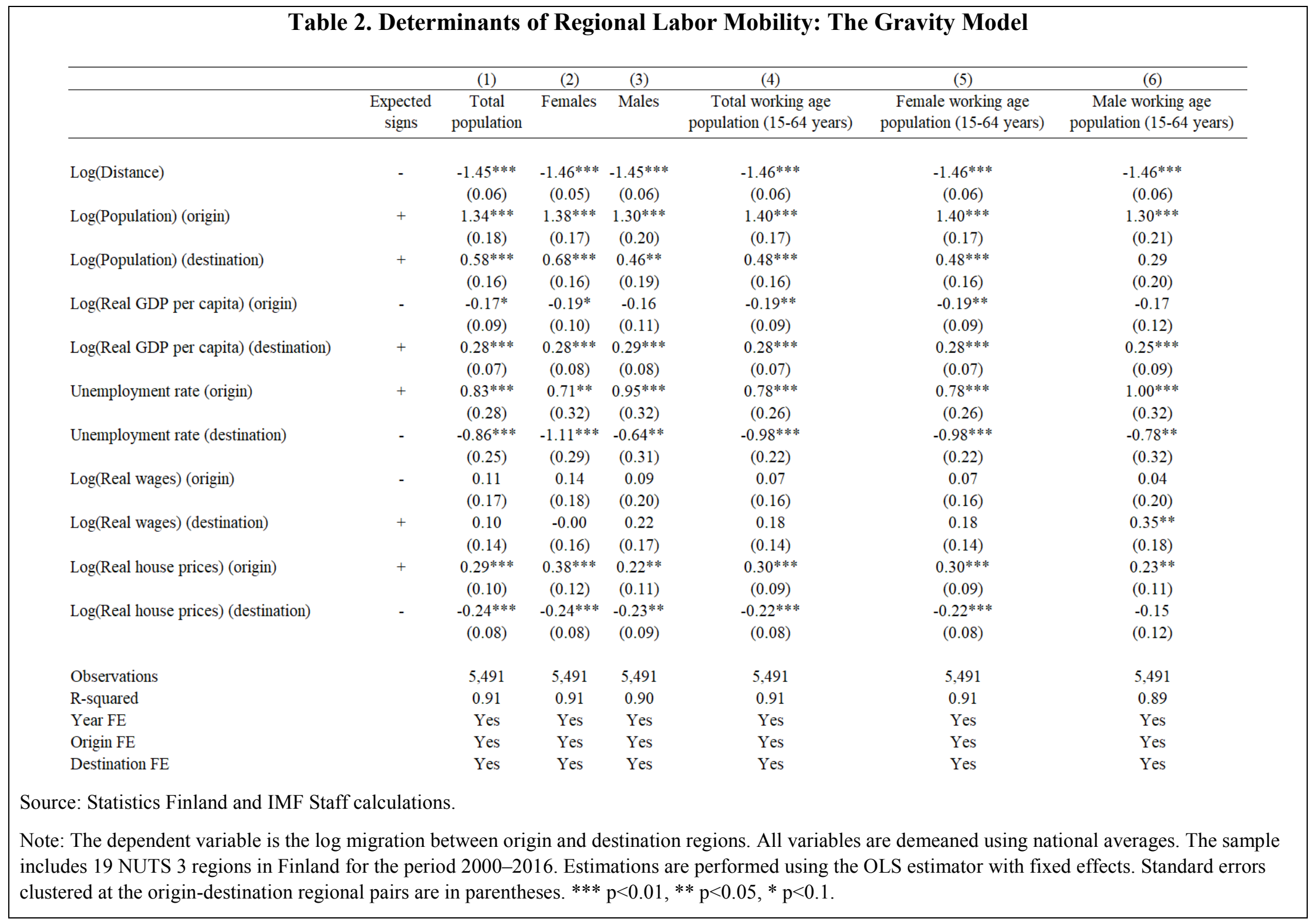




\section{ANNEX I. BLANCHARD AND KATZ (1992) METHODOLOGY}

This annex describes the indirect approach to quantify regional labor mobility in response to a regional labor demand shock proposed by Blanchard and Katz (1992).

The approach is based on the following identity:

$$
\Delta \ln (E)=\Delta \ln \left(\frac{E}{L F}\right)+\Delta \ln \left(\frac{L F}{P O P}\right)+\Delta \ln (P O P)
$$

where $E$ indicates employment, $L F$ is the labor force (the sum of employed and unemployed), $P O P$ is the working age population (the sum of the labor force and out of labor force working age population), $E / L F$ is the employment rate, and $L F / P O P$ is the labor force participation rate.

This identity can be used to predict evolution of a regional labor market following the labor demand shock and decompose the response into changes in regional employment and participation rates and changes in the working age population. As most of the changes in the working age population are due to in- and out-migration rather than demographics, $\triangle \ln (P O P)$ could be interpreted as regional labor mobility.

Blanchard and Katz (1992) draw on the above identity and estimate the following VAR:

$$
\begin{gathered}
\Delta e_{i t}=\alpha_{i 10}+\alpha_{i 11}(L) \Delta e_{i t-1}+\alpha_{i 12}(L) l e_{i t-1}+\alpha_{i 13}(L) l p_{i t-1}+\epsilon_{i t}^{e} \\
l e_{i t}=\alpha_{i 20}+\alpha_{i 21}(L) \Delta e_{i t}+\alpha_{i 22}(L) l e_{i t-1}+\alpha_{i 23}(L) l p_{i t-1}+\epsilon_{i t}^{l e} \\
l p_{i t}=\alpha_{i 30}+\alpha_{i 31}(L) \Delta e_{i t}+\alpha_{i 32}(L) l e_{i t-1}+\alpha_{i 33}(L) l p_{i t-1}+\epsilon_{i t}^{l p}
\end{gathered}
$$

where $\Delta e=\Delta \ln (E)$ is the employment growth, $l e=\ln (E / L F)$ is the log employment rate, $l p=\ln (L F / P O P)$ is the $\log$ participation rate, the parameter $L$ is the lag operator, and $\epsilon$ 's are the stochastic error terms. It is assumed that $\Delta e, l e$, and $l p$ are stationary $I(0)$ variables. National means are differenced out from each variable before the estimation to isolate region-specific shocks from national shocks.

The estimates obtained are used to trace the fluctuations of $\Delta e, l e$, and $l p$ in response to a regional labor demand shock $\epsilon^{e}$. The intuition is as follows (see picture). A labor demand shock has only a temporary effect on employment growth, employment and participation rates, but a permanent effect on the level of employment. Therefore, a positive labor demand shock will permanently increase the level of employment. Given the above identity, higher employment could only be achieved due to higher employment rates (or lower unemployment rates), higher labor force participation rates, and/or increase in the working age population due to in-migration. Since employment and labor force participation rates are stationary, they return to their long-run equilibrium in response to the labor demand shock. Therefore, in-migration by construction explains any permanent change in the level of employment following the positive shock. 


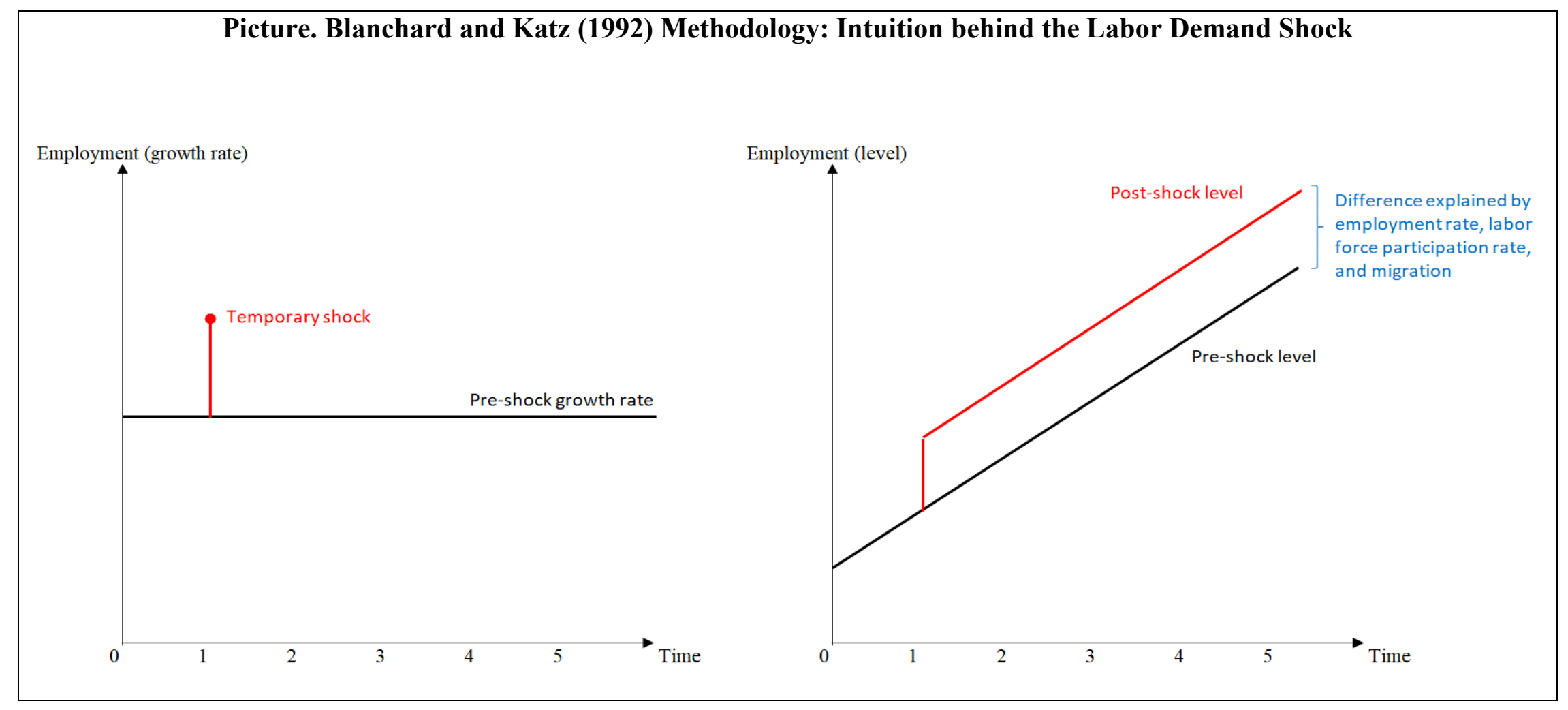




\section{ANNEX II. THE GRAVITY MODEL}

This annex describes the analog of the gravity model popularized in the trade literature to analyze regional labor mobility (see Greenwood 1997; Greenwood 2005 for a survey).

The empirical specification takes the following form:

$\ln \left(M_{i j t}+0.01\right)=\alpha_{0}+\alpha_{1} \ln \left(D_{i j}\right)+\sum_{k=1}^{K} \beta_{k} \ln \left(X_{k i t}\right)+\sum_{k=1}^{K} \gamma_{k} \ln \left(X_{k j t}\right)+d_{i}+d_{j}+d_{t}+\epsilon_{i j t}$

where $i$ denotes the origin region, $j$ denotes the destination region, $t$ denotes time, $M_{i j t}$ is the number of people that have moved from region $i$ to region $j$ in period $t, D_{i j}$ is the geographical distance between origin and destination regions, $X_{i}$ are the factors in the origin region affecting labor mobility, $X_{j}$ are the factors in the destination region affecting labor mobility, $d_{i}$ are the origin region fixed effects, $d_{j}$ are the destination region fixed effects, $d_{t}$ are the time fixed effects, and $\epsilon$ is the residual. All variables are expressed in logs, so that the coefficients can be interpreted as elasticities ${ }^{1}$

Various variables were used in the literature as determinants of labor mobility. These variables include:

- $\quad$ Distance. Larger distances across regional pairs are expected to reduce labor mobility as larger distance implies higher moving costs.

- $\quad$ Population. Out-migration is expected to be larger from more populous regions. Also, more populous regions are expected to attract more in-migrants. These are the gravitational or demographic forces that are equivalent of GDP widely used in the trade literature.

- $\quad G D P$ per capita. Out-migration is expected to be larger from poorer regions. Conversely, richer regions are expected to be an attractive destination for in-migrants.

- Unemployment rate. Out-migration is expected to be larger from regions with higher unemployment rate. Conversely, regions with lower unemployment rates are expected to be an attractive destination for in-migrants.

- Real wages. Out-migration is expected to be larger from regions with relatively lower wages. Conversely, regions with higher wages are expected to attract more in-migrants.

- $\quad H o u s e$ prices. Relative house prices reflect cost of living differentials between regions (Bover and others 1989). Labor is expected to move out from regions with more expensive housing to regions with more affordable housing, ceteris paribus.

\footnotetext{
${ }^{1}$ Given that in some pairs of regions there may be 0 labor mobility in some time periods, a small positive number is added to $M_{i j t}$ to allow for a logarithmic transformation. There are about 200 observations with no labor mobility in our sample and dropping them out of the sample does not have qualitative effect on the results.
} 


\section{References}

Arpaia, A., Kiss, A., Palvolgyi, B., and A. Turrini, 2018, "The Effects of European Integration and the Business Cycle on Migration Flows: A Gravity Analysis," Review of World Economics (forthcoming).

Beine, M., Bourgeon, P., and J-C. Bricongne, 2018, "Aggregate Fluctuations and International Migration," The Scandinavian Journal of Economics (forthcoming).

Bockerman, P., Kosonen, T., Maczulskij, T., and H. Keranen, 2017, “Job Market (In)Flexibility,” Labour Institute for Economic Research Report 34.

Bover, O., Muellbauer, J., and A. Murphy, 1989, "Housing, Wages, and U.K. Labour Markets," Oxford Bulletin of Economics and Statistics, 51(2): pp. 97-136.

Blanchard, O., and L. Katz, 1992, "Regional Evolutions,” Brookings Papers of Economic Activity, 23(1): pp. 1-76.

Böckerman, P., T. Kosonen, T. Maczulskij, and H. Keränen, 2017, “Job Market (In)Flexibility,” Report 34, Labor Institute for Economic Research (Helsinki: Finland).

Choy, W.K., D. Maré and P. Mawson, 2002, "Modelling Regional Labour Market Adjustment in New Zealand," New Zealand Treasury Working Paper No. 02-01.

Debelle, G. and J. Vickery, 1999, "Labour Market Adjustment: Evidence on Interstate Labour Market Mobility," Australian Economic Review, 32(3): pp. 249-63.

Decressin, J. and A. Fatas, 1995, “Regional Labor Market Dynamics in Europe,” European Economic Review, (39): pp. 1627-55.

European Commission (EC), 2018, “Country Report: Finland 2018,” European Commission: Brussels.

International Monetary Fund (IMF), 2014, "Housing Recoveries: Cluster Report on Denmark, Ireland, Kingdom of the Netherlands - The Netherlands, and Spain," IMF Country Report No. 15/1.

International Monetary Fund (IMF), 2015, "Filling the Gap: Labor Market Reforms to Promote Jobs and Growth,” IMF Country Report No. 15/312.

__, 2017, “Finland's Labor Market,” IMF Country Report No. 17/371.

Greenaway-McGrevy, R. and K. Hood, 2016, "Worker Migration or Job Creation? Persistent Shocks and Regional Recoveries," Journal of Urban Economics, 96: pp. 1-16. 
Greenwood, M. J. 1997, “Internal Migration in Developed Countries,” In Handbook of Population and Family Economics (M. R. Rosenzweig and O. Stark, eds.): pp. 647-720 (Amsterdam: Elsevier Science).

— , 2005, "Modeling Migration," In K. Kempf-Leonard (Ed.), Encyclopedia of social measurement, Vol. 2: pp. 725-34 (New York: Elsevier).

Maczulskij, T., Böckerman, P., and T. Kosonen, 2018, “Job Displacement, Inter-Regional Mobility and Long-Term Earnings," Labour Institute for Economic Research Working Paper 323.

Molloy, R., C. Smith, and A. Wozniak (2011), "Internal Migration in the United States," Journal of Economic Perspectives, 3: pp. 173-96.

Moretti, E., 2011, “Local Labor Markets," in Handbook of Labor Economics, Vol. 4b, David Card, and Orley Ashenfelter, eds. (New York: Elsevier).

Marques, H., 2010, "Migration Creation and Diversion in the European Union: Is Central and Eastern Europe a 'Natural' Member of the Single Market for Labour?' Journal of Common Market Studies, 48(2): pp. 265-91.

OECD, 2018, “OECD Economic Surveys: Finland 2018” OECD: Paris.

Pytliková, M., 2014, "The Effect of EU Enlargements and Labour Market Openings on Migration," (Working Paper). Prague: CERGE-EI.

Vainiomäki, J., 2016, The development of wage dispersion and wage rigidity in Finland: The Report to the Economic Policy Council, December 2016.

Visser, J., 2016, "What Happened to Collective Bargaining during the Great Recession?" IZA Journal of Labor Policy, 5(1): pp. 1-35. 